\title{
A PROPÓSITO DE UN \\ NUEVO SELLO MEDIEVAL GALLEGO. \\ El OBISPO DON GONZALO, DE MONDOÑEDO, Y LOS ORÍGENES DE LA CASA DE ALTAMIRA'
}

\author{
FAUSTINo MENÉndeZ PIDAl DE NAVASCUÉS \\ Real Academia de la Historia (Madrid) \\ EDUARDo PARDo DE GUEVARA Y VALDÉS \\ Instituto de Estudios Galegos «P. Sarmiento» \\ (CSIC, Santiago de Compostela)
}

\section{SUMARIO}

1. Descripción y análisis de la matriz secular.-2. Identificación del titular.3. El linaje de los Moscoso en los siglos XIII y XIV.

Hace ya algunos años, un decenio exactamente, se encontró enterrado en un campo de las cercanías de Aviñón un sello matriz español, que había pertenecido -como se verá- a un eclesiástico gallego ${ }^{2}$. El natural interés del hallazgo de este tipo de testimonios, su estudio y consiguiente identifica-

\footnotetext{
'La Dra. Regina Sáinz de la Maza vivió de cerca, allá por 1990, los primeros pasos dados en la identificación del personaje titular de la matriz sigilar de que se trata. Posteriormente, apenas un par de meses antes de su repentino fallecimiento, atendió a nuestro ruego y localizó en bibliografia de circulación muy restringida algunas noticias biográficas que le solicitamos. Por tanto, al publicar estas páginas - que son resultado final de aquella indagación- es natural que consignemos con emoción nuestra gratitud, al tiempo que contribuimos al homenaje de afecto sincero y permanente recuerdo que se le rinde.

'Un primer avance de las consideraciones que sugiere esta nueva matriz sigilar medieval gallega en F. MENÉNDEZ PIDAL DE NAVASCUÉS, Un nuevo sello medieval gallego, "Hidalguía", 256-257 (1996), pp. 329-335.
}

"Anuario de Estudios Medievales", 29 (1999) 
ción, se ve indudablemente redoblado en este caso concreto, en el que a la relevante personalidad de su titular se suma, sobre todo, el número escasísimo de matrices sigilares gallegas que ha llegado hasta nosotros. En realidad, convendrá apuntarlo aquí, ésta es la tercera que ha podido localizarse e identificarse en los últimos años ${ }^{3}$.

Entre los testimonios sigilográficos, las matrices poseen la gran ventaja de ser perfectamente visibles sus figuras y sus leyendas, salvo en el caso poco frecuente de haber sufrido deterioros accidentales, nunca debidos a un uso normal. Por otra parte, no presentan los problemas debidos a la falta de algún trozo o a los desgastes naturales, ciertamente comunes en el caso de las improntas y que hacen irreconocible una parte de su contenido gráfico. Pero, frente a estas últimas, aquéllas tienen en cambio el grave inconveniente de no estar unidas a un acta, lo que dificulta el conocimiento de las circunstancias del titular no facilitadas por la leyenda $y$, muy especialmente, su propia cronología. Por ello, en estas páginas se estudiará primeramente la matriz en sí misma, junto con todo lo que cabe deducir de sus propios carácteres tipológicos. Después, ya se procurará la identificación del titular, contrastando y completando la información con fuentes documentales exteriores.

\section{DESCRIPCIÓN Y ANÁLISIS DE LA MATRIZ SECULAR}

La matriz encontrada, plana y simple, o para sellos de una cara, es de forma polilobulada, como puede verse en el dibujo que se acompaña, y alcanza los $52 \mathrm{~mm}$. de diámetro. Tiene en el centro de su campo un escudo de armas, de la forma llamada española, o cuadrilonga, que lleva cinco cabezas de lobo, y está rodeado por otros cuatro, más pequeños y dispuestos en cruz, jaquelados $(3 \times 3)$ de llanos y de fajados. Entre estos escudos más pequeños se intercalan cuatro veneras. El lector habrá reconocido ya, probablemente, las armas de dos importantes linajes gallegos: los Mosquera y los Ulloa. La leyenda perimetral dice así:

$+s^{\prime}$ GUNDISALVI PETRI ARCHIDIACONI DE AVEANCIS.

Se trata, por consiguiente, de un Gonzalo Pérez, arcediano de Abeancos, dignidad de la iglesia lucense, que era por varonía del linaje de

\footnotetext{
${ }^{3}$ Las anteriores en E. PARDO DE GUEVARA Y VALDÉS, Dos matrices sigilares medievales gallegas en el Instituto Valencia de Don Juan, "Hidalguía", 190-191 (1985), pp. 583-592.
} 
Mosquera y por su madre o abuela del linaje de Ulloa. Adviértase que en el sello se señalan sus linajes paterno y materno únicamente mediante las armas, no mediante apellidos. Las veneras, por lo demás, aluden evidentemente a la Iglesia compostelana.

La interesante manera de precisar la posición genealógica, mediante las armas de dos linajes, es netamente española y más precisamente castellana, desconocida hasta entrado el XIV en el ámbito anglo-francés. La indicación es completada por el inseparable conjunto nombre-patronímico, dado por la leyenda, que fija ya de manera indudable a un solo individuo entre los varios - hermanos, por ejemplo- a los que podrían convenir los dos escudos de armas juntamente. Esta fórmula castellana, propagada enseguida a otras regiones de España, dio origen a un tipo de sello: el llamado cuadrilobulado ${ }^{4}$, cuyo diseño se ajusta a esta idea de mostrar dos escudos de armas - o más generalmente dos emblemas heráldicos- sin necesidad de reunirlos en un solo escudo. En el centro y con un tamaño mayor se dispone el escudo o emblema principal, mientras que los secundarios se sitúan alrededor y con menor dimensión: la precedencia se expresa por las contraposiciones centro-periferia y mayor-menor. Así, por ejemplo, una mujer casada lleva en el centro las armas del marido y alrededor los emblemas de su propio linaje; un hijo puede llevar en el centro el emblema o escudo de armas paterno y los del linaje materno en torno.

Esa fórmula original, dispuesta en un campo cuadrilobulado, comienza a verse en Castilla en tiempos de San Fernando y alcanza su mayor auge hacia el fin del reinado de Alfonso el Sabio, para declinar finalmente ante las nuevas modas que se imponen desde el segundo cuarto del siglo XIV. En la época que aquí más nos interesa - de fines del siglo XIII a fines del XIV - sólo en Navarra y en Cataluña ${ }^{5}$, por el momento, conocemos los sellos con suficiente extensión como para establecer con alguna seguridad su evolución tipológica. Son para eso demasiado escasos los sellos conocidos de Castilla y aún mucho menos los de Galicia. No obstante, algo puede decirse respecto al sello del Gonzalo Pérez para intenar ajustar la época de la fabricación de su matriz. Naturalmente, estos intentos de datación fundados en caracteres tipológicos

\footnotetext{
${ }^{4}$ Para la tipología de las matrices medievales puede verse F. MENÉNDEZ PIDAL y E. GómEZ, Matrices de sellos españoles, Madrid, 1987.

${ }^{5}$ Para los sellos catalanes véase F. DE SAGARRA, Sigil-lografia Catalana, Barcelona, 1916-1932. Para los navarros, F. MENÉndez PIDAL, M. RAMOS y E. OCHOA DE Olza, Sellos navarros de la Edad Media. Estudio y corpus descriptivo. Pamplona, 1995.
} 
o estilísticos son por su misma naturaleza inseguros. Realmente sólo facilitan un límite anterior, porque podremos fijar la época en la que determinados caracteres aparecen, pero nada obsta a que se repita un viejo modelo cuando ya pasó su mayor auge.

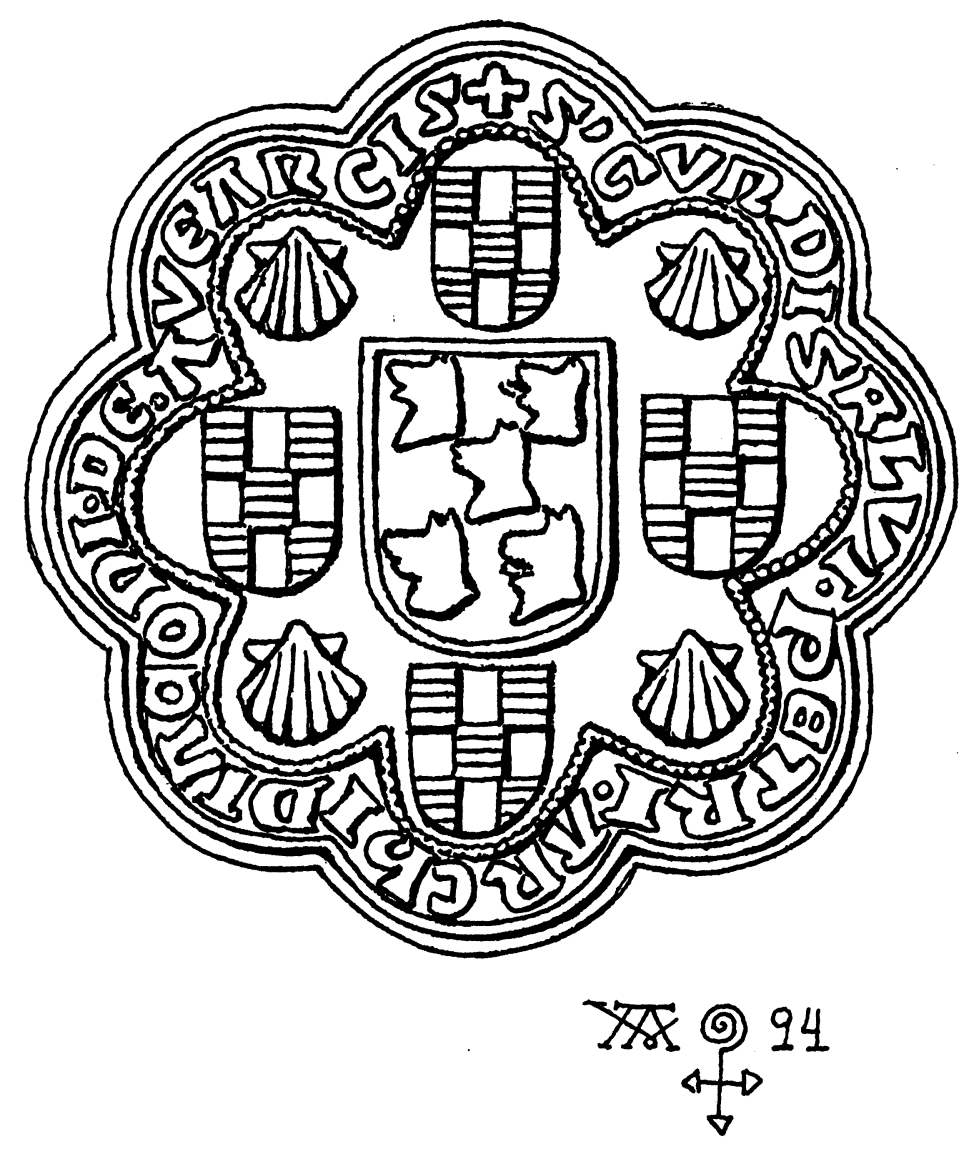

Dibujo de Xosé Antón Garcia G. Ledo

La tipología de la matriz de este Gonzalo Pérez es sin duda derivada de los sellos cuadrilobulados y, en consecuencia, posterior a ellos. Desde los últimos años del siglo XIII, los sellos castellanos acusan una tendencia a la novedad, consecuencia probablemente de un cierto cansancio de las formas tradicionales que se percibe también en otros objetos. A las formas escuetas 
y sencillas de antes se prefieren ahora las más complicadas y ricas en detalles. Nacen así, en los sellos, las formas perimetrales primero trilobuladas, más tarde estrelladas, polilobuladas, etc., aún manteniendo el concepto emblemático del sello cuadrilobulado, pero no su forma externa, como ocurre en el de Gonzalo Pérez. La cronología de este proceso no es naturalmente coincidente para todos los casos, porque las nuevas modas se difunden poco a poco, transmitiéndose de unas regiones a otras y de unas clases sociales a otras, en general en sentido descendente. Con las salvedades antes dichas, la matriz de Gonzalo Pérez corresponde tipológicamente a un período no anterior a los años finales del siglo XIII, cuyo límite posterior vendría marcado por la llegada de las novedades que se van introduciendo desde el segundo tercio del XIV. Los nuevos modelos son, en general, de módulo más pequeño, adaptado al uso de sellar en placa, ahora casi exclusivamente utilizado, y desaparece la costumbre de usar dos armerías separadas (fórmula del cuadrilobulado), sustituidas por un solo escudo, que a finales del siglo o principios del XV se presentará inclinado bajo un yelmo con cimera.

Cuestión importante que merece también consideración es que el sello del arcediano de Abeancos -o al menos éste de que tratamos, pues pudo disponer de otro- no es de tipo eclesiástico. Su condición de tal no se manifiesta en el sello sino en la leyenda y en la discreta alusión al arzobispado de Santiago mediante las veneras. Pero éste no es hecho muy raro en clérigos pertenecientes a linajes importantes, que encontraban preferible esta manera de expresar a los demás su propia personalidad social ${ }^{6}$. En otras palabras: consideraban de mayor relieve social y más trascendente pertenecer a esos linajes que poseer un beneficio eclesiástico. Los sellos de tipo eclesiástico evolucionaron también, aunque de modo menos acusado: la imagen del propio sigilante, sea obispo o abad, que contienen los más antiguos, disminuye de tamaño a fines del XIII, convirtiéndose en un minúsculo orante entre dos escudos de armas; la figura terminará por desaparacer, permaneciendo sólo la identificación heráldica.

Convendrá asimismo examinar los otros testimonios sigilares conocidos de este linaje Moscoso o Mosquera, que cabe suponer ya uno mismo a la vista de la identidad de las armas. Es sabido que la repetición o la alternancia invertida del conjunto inseparable de nombre y patronímico fue uno de los

\footnotetext{
'Un buen ejemplo de ello en el de Simón Ruiz, arcediano de Carrión por 1247, dispuesto en forma de escudo, con el jaquelado de su linaje de Girón (Archivo de la Catedral de Toledo).
} 
recursos empleados como signo de identidad del linaje, antes de que se difundiese el uso de un apellido estable. El apellido, además, era normalmente impuesto desde fuera y luego aceptado por los individuos del linaje. Las armas, por el contrario, eran adoptadas por éstos y luego dadas a conocer a los demás. Tal situación es la que claramente reflejan los sellos: se omite el apellido, todavía no establecido, y la identidad o designación del linaje se encomienda a los emblemas heráldicos.

Además de la matriz hallada en Aviñón se conocen otros dos testimonios sigilares con las armas de los Moscoso y pertenecientes también, curiosamente, a sendos personajes llamados Gonzalo Pérez, cuya identificación avanzaremos con suficiente claridad más adelante. En primer lugar, la mención de una impronta del sello de un arcediano de Reina en la iglesia compostelana, nombrado Gonzalo Pérez - como queda dicho ya - en el año de $1373^{7}$. Su descripción se incluye en el traslado notarial de un documento, señalándose que éste «... era scripto en pulgamêo et firmado de nome do dito Gonçalvo Pérez, arçidiago, et era seellado de hun seello enpendente, que era signado no dito seello cabeça de lobo, et colgado en huna baraça de lina marqada...». En el documento, nuestro personaje se titula "Gundisalvus Petri, archidiaconus de Regina in ecclesia compostellana ac generalis vicarius, archidiaconus de Salnes in predicta ecclesia compostellana». Según la descripción, por tanto, las armas de este importante eclesiástico eran una cabeza de lobo.

Por último, el tercer sello entre los que hoy se conocen corresponde también a otro Gonzalo Pérez. De él se dispone solamente un vaciado en la colección del Archivo Histórico Nacional, sin que puedan recabarse noticias comprensibles acerca de su procedencia y data exacta ${ }^{8}$. Es en forma de escudo redondeado por la punta, que lleva en su campo cinco cabezas de lobo, rodeado por la leyenda, desgraciadamente de difícil lectura en su última parte: $+S^{\prime}$ GO(N)CALO PEREZ CAVALL(ER)O DE M...

El problema de la identificación de este tercer testimonio podría ser análogo al que plantean las matrices: sólo los escuetos datos de la leyenda y una cuidadosa investigación genealógica - tal como la que se ofrecerá a

${ }^{7}$ M.X. Justo Martín y M. LuCas, Fontes documentais da Universidade de Samtago de Compostela, Santiago, 1991, doc. núm. 243: Gonzalo Pérez otorga un título colativo de un beneficio en Santiago, año de 1373.

${ }^{8}$ Número 940 . La papeleta redactada a principios de siglo por don Juan Menéndez Pidal, cuando formó la Sección de Sigilografía, da unas signaturas que no se corresponden con las actualmente vigentes en el AHN. 
continuación- pueden conducir a hipótesis verosímiles ${ }^{9}$. El tipo de este nuevo sello poco nos puede aclarar, porque tuvo una larga vigencia: en uso desde el segundo cuarto del siglo XIII, llega a penetrar en el XV en algunas regiones y niveles sociales.

Es preciso añadir todavía algún comentario respecto a la diversidad en el número de las cabezas de lobo que figuran en los sellos mencionados. Para comprender esta cuestión en sus debidos términos se ha de partir del análisis de la manera de usar estos emblemas gráficos en la primera etapa de su existencia, que se puede fijar, para la región gallega, hasta los años finales del siglo XIV. La significación se fija en lo que entonces se denomina la señal, la cabeza de lobo en este caso; esta señal se presenta en cada soporte según pautas adecuadas a la forma y tamaño de la superficie a llenar. No importa pues, en principio, el número de veces que se repite, porque ese número en nada altera la significación ${ }^{10}$. Pero no es éste el único factor a tener en cuenta. Está, primero, la tendencia a fijar esas pautas de presentación de la señal en el campo del escudo, de tal modo que la misma pauta se hace significante y en consecuencia por fin inamovible. Este proceso se inicia a mediados del $\mathrm{XIV}$ y culmina ya entrado el XV. Entonces, las variantes en las pautas, que antes se habían considerado no significantes, pueden aprovecharse para diferenciar armas, bien de individuos de la misma rama del linaje, bien de ramas ya separadas ${ }^{11}$. Por último, parece notarse en la segunda mitad del XIV una inclinación a complicar las armerías multiplicando el número de las figuras que las componen. De ello hay numerosos ejemplos que sería poco oportuno describir aquíl' ${ }^{2}$. Tal gusto por la complicación, por la riqueza de los detalles, encaja perfectamente con las modas del momento, que se

\footnotetext{
${ }^{9}$ Lástima grande que los sellos de personajes particulares hayan sido casi siempre preteridos en España por los sigilógrafos ( ¿a causa de su contenido básicamente heráldico?) en claro contraste con la atención que han merecido los reales y eclesiásticos.

${ }^{10}$ Un ejemplo de esta misma época - principios del siglo XIV - se halla en el sepulcro de doña Inés que acompaña al de su esposo, el infante don Felipe, en la iglesia de Villacázar de Sirga (Palencia). En los escudos que se repiten enmarcando el frente, las armas de los Mendoza se representan con tres, cinco o seis panelas indistintamente.

"De este modo se diferencian, por ejemplo, las armas de los reyes de Aragón (cuatro palos) de las que usan los condes de Foix (tres palos, con los mismos colores), que primitivamente se tenían por unas mismas.

${ }^{12}$ Un buen ejemplo en los sellos de Pedro Sánchez de Monteagudo, señor de Cascante, que en 1272-1276 trae un águila, y de su hijo Juan Sánchez, de 1281, que lleva tres águilas. Véase, F. Menéndez Pidal, M. Ramos y E. OChoa de Olza, Sellos medievales de Navarra, estudio y corpus descriptivo, núms. 2/1698 y 1701 .
} 
manifiestan tanto en el campo emblemático - caso bien conocido, que no exclusivo, de las cimeras y divisas - como en otros muy alejados, como la indumentaria principalmente.

\section{IDENTIFICACIÓN DEL TITULAR}

Como se expresa en la leyenda perimetral y queda indicado más arriba, la matriz sigilar de que se trata perteneció a un Gonzalo Pérez, arcediano de Abeancos, dignidad de la iglesia lucense. Por otra parte, ahora de acuerdo con las armerías que en el campo de aquélla se disponen, el personaje pertenecía por varonía al linaje de los Moscoso o Mosquera, mientras que por su madre -o acaso abuela - procedía de la estirpe de los Ulloa.

El tal nombre y patronímico unido a la condición eclesiástica del personaje no son, naturalmente, circunstancias personales suficientes para alcanzar la deseada identificación. En realidad, sólo con una muy somera revisión documental es fácil descubrir a varios eclesiásticos gallegos homónimos y con un cursus honorum que cabe situar dentro del marco cronológico de referencia ${ }^{13}$. Así, sólo por citar algunos de ellos, el Gonzalo Pérez Corvacho, que figura como canónigo compostelano a mediados de siglo y ya como chantre desde $1368^{14}$, o el también canónigo compostelano Gonzalo Pérez, que se documenta al poco de mediar la centuria, en concreto por 1352, cuando fue comisionado por el Cabildo de su iglesia para resolver el pleito que éste sostenía por la aldea de Pieros, o Peeryros, en tierras del Bierzo ${ }^{15}$. Otro, aunque sin duda ya mucho más significativo, pues él mismo se identifica con el apellido Moscoso, es justamente el Gonzalo Pérez que figura -avanzada un tanto la segunda mitad del siglo- como arcediano de Reina y vicario

\footnotetext{
${ }^{13}$ El vaciado de eclesiásticos compostelanos es cortesía que debemos a la amabilidad del Dr. F. J. Pérez Rodríguez.

${ }^{14}$ Véase, A. López Ferreiro, Historia de la Iglesia de Santiago, vol. VI, Santiago, 1903, p. 277 y Apéndices, 141.

${ }^{15}$ La tal aldea había sido donada por doña Juana de Castro a doña Milia Pérez, su medio hermana, con la obligación de celebrar tres aniversarios, uno por el padre de ambas, don Pedro Fernández de Castro el de la Guerra, y los otros dos por doña Juana y la propia doña Milia y su marido. En su testamento, esta última la dejó al cabildo compostelano, pero su viudo, Vasco Pérez de Vaamonde, se resistió reiteradamente a entregarla. Véase, Libro Antiguo de Tenencias del Cabildo Compostelano, comenzado en 1352, fol. 181. La referencia y el texto en A. LóPEZ FERREIRO, Galicia Histórica, CD, doc. núm. XXX, pp. 144-146, y una detenida exposición del pleito por el mismo en Historia de la Iglesia de Santiago, vol. VI, pp. 273-274 y 284-285.
} 
general del arcedianato de Salnés, lo que permite identificarlo, sin reserva ninguna, con el propietario de uno de los sellos más arriba mencionados.

En principio, desde luego, este último personaje podría adecuarse muy bien al perfil del titular de la matriz sigilar de referencia. Coincide con él en lo fundamental, o acaso cabría decir en lo más general: la cronología estimada, el nombre y patronímico, el linaje de varonía y la condición eclesiástica. Frente a ello, no consta su dignidad de arcediano de Abeancos, aunque ésto es algo que podría obviarse; bastaría con suponer su posible acceso a la tal dignidad en fecha o momento indeterminado. Sin embargo, la existencia de ese otro sello ya mencionado más atrás -en el que se figura sólo la señal de los Moscoso- y que consideramos indudablemente suyo, así como la dificultad para explicar de forma satisfactoria la combinación de esa señal heráldica de varonía con el más elaborado emblema de los Ulloa, invitan a rechazar definitivamente la posibilidad contemplada ${ }^{16}$.

Por fortuna, la indagación bibliográfica - simultánea a la propia revisión de las fuentes publicadas- permite descubrir otros personajes homónimos dentro del estamento eclesiástico gallego de la época de referencia. $Y$ en este contexto, la dignidad eclesial ostentada por el propietario de la matriz resulta por fin determinante. En la nómina de los sucesivos titulares del arcedianato de Abeancos que figuran en la documentación de aquellos tiempos, compuesta para este fin, aunque probablemente no sea exhaustiva, se documenta un Gonzalo Pérez entre los últimos años del siglo XIII y primeros del XIV. La identificación es ahora incontestable, pues se trata de un personaje - lo avanzaremos ya- que resulta ser miembro de la estirpe de los Moscoso e hijo, además, de una Ulloa ${ }^{17}$.

\footnotetext{
${ }^{16}$ Como se verá en su lugar, este Gonzalo Pérez de Moscoso es personaje bien conocido y perfectamente documentado. Hijo de Sancho López, nieto muy probablemente de un Lope Pérez, que es el primero de todos los que llevaron tal nombre y patronímico, y segundo nieto -él mismo lo afirma en cierto instrumento - de don Pedro Vidal y de doña Teresa Sánchez de Ulloa. De esta genealogía se deduce con claridad, por consiguiente, que hubiera resultado un tanto forzado - por inusual o insólito para las costumbres de la época- que este personaje dispusiera en su sello las armerías del linaje de su segunda abuela.

${ }^{17}$ Véase, P. D. Calonge, Los tres conventos franciscanos de Orense, Orense, 1949, pp. 145-146 y 169. En 1307 un Gonzalo Pérez, titulado arcediano de Abeancos, actua como confirmante en un convenio entre el Arzobispo compostelano y el caballero Payo Mariño, hijo de don Pedro Paes Mariño, repostero de Fernando IV; RAH. En fechas posteriores se asoman de cuando en cuando a la documentación otros titulares de la dignidad: Johannis Martín (1324), Juan Fernández (1326), otra vez Johannis Martín (1327-1341), Alvaro Díaz (1388) y Juan Díaz (1400); vease, A. LÓPEZ FERREIRO, Historia de la Iglesia de Santiago, vol. VI, Apéndices, 77 y 116, y también Archivo de la Catedral de Lugo [en adelante sólo ACL], Colección Piñeiro, vol. IV, fol. 11.
} 
La información documental, aunque en principio parca y nada significativa, va alumbrando poco a poco la trayectoria de este clérigo, propietario de la matriz objeto de estas páginas, y termina por descubrirnos - como se verá a continuación - una de las personalidades más relevantes de la Iglesia gallega del primer cuarto del siglo XIV.

Por lo que hace a la trayectoria eclesiástica de este personaje, la noticia más temprana se remonta a los últimos años del XIII y se vincula al largo proceso eclesiástico sustanciado tras el asalto, quema y despojo del convento franciscano de Orense, sito en el llamado Barrio Nuevo de aquella ciudad. El suceso, acaecido un día de mayo de 1289, estuvo instigado -aunque los motivos no aparezcan suficientemente claros-por el propio obispo auriense, don Pedro Yáñez de Noboa. En el curso del mencionado proceso, Bonifacio VIII despachó una Bula - firmada en Letrán, el 25 de mayo de 1296comisionando «a los venerables hermanos el Arzobispo Compostelano, Obispo de Mondoñedo y al amado hijo el Arcediano de Aveancos, en la Iglesia de Lugo" para que citaran a los responsables del latrocinio y que «dentro de tres meses después de vuestra citación, se presenten personalmente ante la Silla Apostólica, para recibir el merecido y hacer acerca de estas cosas lo que la justicia manda ${ }^{18}{ }^{2} .$. Como es fácil adivinar, el amado hijo que se menciona en el Breve Pontificio no es otro que don Gonzalo Pérez de Moscoso, cuyo nombre y patronímico figura unido indistintamente a su dignidad de arcediano de Abeancos o de canónigo de Santiago en otros documentos pontificios, como recoge P. Doroteo Calonge al ocuparse de aquellos acontecimientos ${ }^{19}$. Así, por ejemplo, en el encabezamiento de la Bula de Clemente V, expedida el 15 de marzo de 1308 y dirigida «al benerable hermano Rodrigo, arzobispo compostelano, y a los amados hijos, arcediano de Cornado y Gonzalo Pérez, canónigos de la Iglesia compostelana.... ${ }^{20}$. Convendrá precisar aquí algo que ahora se hace evidente: que las veneras jacobeas presentes en la matriz sigilar estudiada no tienen un valor testimonial más o menos vago o impreciso, sino un sentido alusivo tan concreto como la de expresar la pertenencia de su titular al cabildo compostelano.

\footnotetext{
${ }^{18}$ El texto latino del Breve Pontificio en el Bullarium Franciscanum, vol. IV, Roma, 1768, 395. Una edición de éste en J. Domínguez FonTEnLa, Breve del Papa Bonifacio VIII, "Boletín de la Comisión Provincial de Monumentos de Orense", X (1934), p. 265. Referencias y comentarios en P.D. CALONGE, Los tres conventos franciscanos de Orense, pp. 146 y ss.

I9Ibidem, pp. 159-163.

${ }^{20}$ Ibidem, p. 160.
} 
El canónigo y arcediano gallego, que era además juez apostólico delegado, dio en pocos años un salto cualitativo en su trayectoria eclesiástica. A mediados de julio de 1313 , le fue concedida una nueva canongía, ahora en la Iglesia de León. Por lo que parece, para entonces ya contaba en Avignon con un muy importante valedor, don Jacobo C. de Stephaneschi, cardenal de San Jorge al Velabro ${ }^{21}$. De ahí, también, que al propio tiempo se le diera licencia para conservar los prestimonios y beneficios que ya poseía, siempre y cuando la renta anual de sus frutos no excediera los 500 florines. Y de entre aquéllos consta que percibía los de Conchis, Piloño, Lestedo, San Martín de Calvos, San Tursi (Tirso?), San Pedro de Ardemil, San Cristóbal de Vesono, Santa Eulalia de Anegondo (Abegongo?) y Santa Eulalia de Portela ${ }^{22}$. Aunque éstos no eran naturalmente su único respaldo económico. A ellos cabría añadir todavía otros ingresos de carácter y naturaleza diversa; entre ellos, por ejemplo, los votos llamados de Santiago que la Iglesia de Lugo cobraba en el partido de Dorra, que él mismo había arrendado en 1308 «pro centum morapetinis annuatim, pro quibus dat fidejussorem dominum Ferdinandum Joannis archidiaconum de Sarria, praesentem et concedentem ${ }^{23}$.

A la vista sólo de esta primera parte de la trayectoria de don Gonzalo Pérez, apenas esbozada aquí en sus rasgos más generales, no sería difícil explicar el hallazgo de su matriz sigilar en las cercanías de la mencionada villa francesa, aunque cabe añadir también que la presencia allí de un eclesiástico gallego no resulta en modo alguno extraña para el momento de que se trata. El buen clérigo gallego, por tanto, perdería su sello matriz junto a la corte de los Papas en no sabemos qué ocasión o peripecia. Es fácil suponer, no obstante, que ésta pudo muy bien estar relacionada con el largo pleito seguido por los sucesivos titulares del arcedianato de Abeancos, consecuencia de las encontradas pretensiones de las iglesias de Santiago y Lugo $^{24}$, o simplemente con alguna de las comisiones que se le hicieron en

\footnotetext{
${ }^{21}$ Amplia información sobre este personaje en I. HöSL, Kardinal Jacobus Caietani Stephaneschi. Ein Beitrag zur Literatur und Kirchengeschichte des Beginnenden vierzehnter ahrhunderts, Berlín, 1908.

${ }^{22}$ Regestum Clementis Papae V, Año V, 349 [in prioratu de Grausello, 17 de julio de 1313].

${ }^{23}$ Véase, J.A. DEL CAMINO, Nueva demostración sobre la falsedad del privilegio del rey don Ramiro I, "Memorias de la Real Academia de la Historia", vol. IV (1805), p. 34.

${ }^{24}$ Por lo que parece, éste debate se prolongó después durante mucho tiempo. Consta. cuanto menos, que proseguía aún a comienzos de la centuria siguiente, por 1407. Así lo manifiesa don Diego López, arcediano de Deza y canónigo de Santiago, al mandar en su testamento -otorgado justamente en San Maximin (Aix), el 21 de agosto del mencionado año- treinta francos de oro
} 
su ya mencionada condición de juez apostólico delegado. Así, por ejemplo, consta que en febrero y junio de 1317, don Gonzalo Pérez fue comisionado junto con otras dignidades esclesiásticas para intervenir en dos asuntos concretos. El primero de ellos sobre la percepción de sus beneficios por un clérigo andaluz, Lope López, canónigo de Córdoba ${ }^{25}$; el segundo, a su vez, sobre la confirmación de otro clérigo, Rodrigo Pérez de Vea, en la titularidad de la parroquia de San Pedro de Caroazia, en la propia diócesis compostela$\mathrm{na}^{26}$. Pero no debe olvidarse tampoco que, por este tiempo, don Gonzalo parece que aspiraba ya a más altos destinos eclesiásticos y ello, como parece lógico, pudo ser motivo de alguna nueva estancia cerca de la corte pontificia.

Como tal clérigo aspirante consta que no fue ajeno a los difíciles momentos que se vivieron en Santiago tras la muerte del arzobispo don Rodrigo de Padrón, que había regido la archidiócesis entre los años 1305 y 1316. El ambiente dentro del Cabildo comenzó a mostrarse singularmente enrarecido entonces, tanto que éste la tensa situación puede considerarse verdadero anuncio de los disturbios que en breve se desencadenarían. Así, cuando llegó la hora de elegir nuevo prelado, aquél se dividió en dos bandos: uno partidario de don Rodrigo Yáñez de Parada, arcediano de Nendos, y otro que lo era ya de don Alfonso Eáns, juez de $\mathrm{Luou}^{27}$. La situación, aunque dibujada así por López Ferreiro, se manifestó sin duda con perfiles mucho más complejos, adquiriendo por fin tintes bélicos cuando, apenas unos meses después, en 25

"a o archidiacono daveanquos, meu tío, para que se siga aquí seu pleito...» Véase, A. LÓPEZ FERREIRO, Historia de la Iglesia de Santiago, vol. VI, Apéndices, 24 y ss.

${ }^{25}$ Véase, G. MolLAT, Jean XXII (1316-1334). Lettres communes, vol. I, p. 257, doc. núm. 2772. La referencia exacta es como sigue: [Al margen: 9 de febrero de 1317 (Datum Avenione) T. X, XII]. Indult. Lupo Lupi, can. Corduben., ut, insistens scolasticis disciplinis in loco ubi vigeat studium generale, possit, usque ad quinquennium, fructus benef. suorum integre percipere. I. e. m. ep. o Giennen., et archid. de Avancis Lucen., ac thesaur. Giennen. eccl. (A. 6, f. 23b; $V .65$, ep. 2596.). También, doc. núm. 2773. La referencia exacta es como sigue: [Al margen: 9 de febrero de 1317 (Datum Avenione) T. XI, XIII]. Eid. gratia exsp. dign., vel personatus, seu off. c. c. vel s. c., cum praestimoniis et benef. praestimonialibus eccl. Corduben.; non obst. in ead. et in Giennen. canon et praeb., et in dicta Giennen. eccl. archidiac. I. e. m. ut s. $(A$. 6 , f. $238 \mathrm{a} ;$ V. 65, ep. 2737).

${ }^{26}$ Ibidem, vol. I, p. 376, doc. núm. 4101. La referencia exacta es como sigue: [Al margen: 16 de junio de 1317 (Datum Avenione) T. XIII]. De Avantio Lucen., cap. PP., et de Sabugali archid. is, et Alphonso Joannis de Lex, can. Compostellan. eccl., mand. ut, inquisita rerum veritate, confirment Rodericum Petri de Vea in possessionem rectoriae paroch. eccl. s. Petri de Caroazia, Compostellanae di., in cujus favorem auditor causarum sacri sacri palatii jam sententiam promulgavit contra Joannem dictum senioren, olim rectorem ejusd. eccl., qui se non fecerat infra annum in presb. promoveri, juxta constit. Lugdunen. concilii novissime celebrati $(A$. 7 , f. 209b; V. 66, ep. 3786).

${ }^{27}$ A. LÓPEZ Ferreiro, Historia de la Iglesia de Santiago, vol. VI, p. 7 y ss. 
de julio de 1317, Juan XXII procedió a la designación de Fr. Berenguel de Landoira. Pero lo que interesa destacar aquí es que, al anotarse la colación del arzobispado, por despacho datado en Avignon justo diez días antes, la propuesta se justifica en razón de la discordia existente en el seno del Cabildo compostelano, cuyos miembros dividían su apoyo en aquel momento entre los varios candidatos que se mencionan, siendo uno de ellos el propio Gonzalo Pérez, si bien López Ferreiro no lo anote en ningún momento ${ }^{28}$.

Aunque su candidatura no alcanzó el refrendo necesario, es indudable que nuestro personaje no perdió los firmes apoyos que le habían respaldado tanto en Compostela como sobre todo en la propia corte papal de Avignon. Así se explica que apenas poco más de un año después, el 20 de diciembre de 1318, don Gonzalo Pérez fuera promovido para regir la diócesis de Mondoñedo, vacante por el reciente fallecimiento del obispo don Rodrigo Vázquez, que la había gobernado desde el año 1298.

El pontificado de don Gonzalo, que debía rondar entonces los sesenta años, no fue especialmente dilatado, poco más de un lustro. Por ello, es natural que sus frutos no fueran especialmente significativos $\mathrm{y}$, por consiguiente, que la huella dejada en el episcopologio mindoniense resulte algo endeble ${ }^{29}$. El comienzo de aquél lo concreta $\mathrm{C}$. Eubel en el 14 de enero de 1319 , si bien el primer documento conocido de su actuación al frente de la diócesis se retrasa - como apunta E. Cal Pardo- al 24 de septiembre de aquel mismo año ${ }^{30}$. De los documentos conservados consta, por de pronto, que su situación económica en aquellos primeros momentos no era muy satisfactoria y que, como consecuencia de ello, hubo de preocuparse por reunir líquido suficiente para satisfacer la servitia communia -o tasa de provisión - a la Cámara del Papa. Se explican así tanto los diversos arrendamientos otorgados a particulares

\footnotetext{
${ }^{28}$ Véase, G. Mollat, Jean XXII (1316-1334). Lettres communes, vol. I, p. 406, doc. núm. 4419. La referencia exacta es como sigue: [Al margen: 15 de julio de 1317 (Datum Avenione) T. VILXX] Berengarius, O.F.P., praeficitur in archiep.um eccl. Compostellan. vac. per obit. Roderici praevia reservat. et per cessionem Roderici Joannis, archid. de Nendes in ead. eccl., Gundisalvi Petri, ejusd. eccl. can., et Alphonsi de Hispania, PP. cap., decani eccl. Ilerden., in ord. et aetate defectum patientis, in discordia a capit. electorum. I. e. m. capit., vassallis, suffraganeis eccl. Compostellan.; clero et populo civit. et di.; Alphonso regi Castellae et Legionis. (A. 7, f. 384b; V. 66, ep. 4090.)

${ }^{29}$ Brevísimas noticias sobre su episcopado en R. SANJURJo y PARDO, Los obispos de Mondoñedo, vol. I, Lugo, 1854, p. 50. Una semblanza reciente y desde luego mucho más ajustada y completa en E. CAL PARDO, Episcopologio mindoniense. Baja Edad Media, "Estudios Mindonienses", 14 (1998), pp. 568-572.

${ }^{30}$ Hierarquía Catholica, Monasterii, 1913, p. 343, y E. CAL PARDO, Episcopologio mindoniense, p. 568.
} 
como la obligación contraída con el Cabildo, ya en agosto de 1322, sobre todos sus frutos y réditos hasta la cuantía de 20.000 maravedíes, que eran exactamente - por lo que parece- los que le restaban pendientes de pago de la mencionada tasa ${ }^{31}$.

Más allá de esta cuestión, que fue efectivamente el móvil que explica algunas de sus primeras actuaciones, merece mención aparte el convenio que suscribió con el Concejo mindoniense, en 22 de junio de 1320 , al objeto de completar la construcción de las murallas de la ciudad, estipulándose que la nueva obra debería llevar cimientos profundos y alcanzar la altura, anchura y solidez de la parte ya construida. En virtud del tal convenio, el obispo y el propio Cabildo financiarían una parte de ella, desde la Puerta de la Fuente hasta la rúa de Batitalas, mientras que el coste de la parte restante lo asumiría ya el Concejo $^{32}$. Las otras medidas llamativas que merecen ser recordadas, o simplemente mencionadas, tuvieron ya un carácter muy diferente. Así, por ejemplo, la convocatoria de Sínodo - las reuniones se celebraron en agosto de 1324- y la redacción de una constitución en la que, en atención a los quebrantos económicos que padecían los clérigos por causa de las tercias reales, impuestas años atrás, se les concedía a éstos los frutos y rentas de sus beneficios por espacio de un año después de su muerte ${ }^{33}$. O también, la prohibición de las plañideras, o neniae, estableciendo bajo pena que tan abominable constumbre no se admitiera tanto durante la conducción del cadáver a la iglesia, como durante el canto de las Horas en el claustro, en el momento del sepelio. Atajó además el absentismo de algunos canónigos, estableciendo las oportunas penas, y reguló y fijó el abono de ciertas cantidades para ornamentos por derecho de enterramiento para dignidades y canónigos de la Catedral.

Aunque no consta la fecha exacta de su fallecimiento, se sabe que ocurrió unos pocos días antes del 5 de enero de 1327, fecha en que el canónigo Juan Eanes lo menciona en su propio testamento, añadiendo la acostumbrada

\footnotetext{
${ }^{31}$ Ibidem, pp. 568-569. Abonos de naturaleza semejante por otros prelados gallegos de aquellos años figuran asentados en E. GöLLER, Die Einnahmen der Apostolischen Kammer unter Johann XXII, Paderborn, 1905, pp. 209, 223 o 276.

${ }^{32}$ Ibidem, p. 569.

${ }^{33}$ En reconocimiento, los clérigos concedieron al Obispo 20.000 maravedíes, cantidad que le permitió liberarse del ya mencionado adelanto hecho por el Cabildo. Ibidem, pp. 569-570.
} 
coletilla que Deus perdone ${ }^{34} \ldots$ Según parece, don Gonzalo fue enterrado en la propia catedral mindoniense, si bien se desconoce el lugar concreto, pues las pocas referencias disponibles se contradicen. Así, por ejemplo, mientras su sobrino Ruy Sánchez, arcediano de Salnés y canónigo de Mondoñedo, afirmaría bastantes años después - por 1357-que sus restos reposaban en la capilla de San Andrés, un documento otorgado en 1368 por otro sobrino suyo, el arzobispo don Rodrigo, se afirma que fue enterrado en la capilla de la Magdalena ${ }^{35}$. Pero ocurre que esta capilla no existía en tiempos de don Gonzalo, sino que fue fundada por el mencionado donante. Es muy posible - lo entiende así Cal Pardo, a quien seguimos- que los restos de aquel prelado fueran trasladados a la mentada capilla, con lo que podrían armonizarse las dos afirmaciones opuestas. Mientras tanto, en el testamento del propio obispo don Gonzalo, otorgado en 29 de diciembre de 1326, nada se aclara respecto a esta cuestión, limitándose a reflejar confusamente sus deseos:

\begin{abstract}
... que me ponan enno terreo, et que aly envii o meu spiritu para aquel sennor quemo en mío corpo meteu, et que me leven a o espital et me ponan enno leyto dos pobres, et desi que me soterren hu quiseren con esses outros pobles. Et se por ventura por feyto das sentenças o no poderen facer, que me ponan
\end{abstract}

\footnotetext{
${ }^{34}$ Ibidem, p. 571. En una anotación documental desconcertante, aunque es más probable que se trate simplemente de una confusión, se alude a don Gonzalo -es él indudablemente porque se especifica que fue elegido en discordia y que obtuvo en 1318 el obispado de Mondoñedoy se señala que desde la sede mindoniense fue transferido al arzobispado de Cagliari, o Calaritano, mencionándosele además como auditor de la Rota a comienzos de agosto de 1331. Véase, B GuILlemain, La corte pontifical en Avignón, París, 1966, p. 35, nota 511. Ello estará en relación con otro asiento documental que figura en G. MOLLAT, Lettres communes de Jean XXII (13161334), vol. XI, p. 77, doc. núm. 55643: (Al margen: 15 de noviembre de 1331, XVII kal dec. (Datum Avenione) T. XV, XVII] Mag. Petro Genesta, PP. familiari. Paroch. ecclesia s. Jacobi de Carnificina Parisien. per obitum Guillelmi Rasseti vacans. et dispositioni PP. reservata mag. Petro de Vico motu proprio collata fuit; demum inter eumdem et Guillelmum Raynardi, ad se dictam eccl. pertinere legitime praetendentem, orta super eadem eccl. materia quaestionis et causa per apellationem dicti Guillelmi Raynardi ad S. A. devoluta Papa causam Gondisalvo, archiep. o Calaritano, tunc capellano apostolico et auditori causarum primi gradus nostri palatii primo et demum Bertrando, archiep. o Ebredunen., audiendam commisit, coram quo lite pendente idem Petrus de Vico extra romanam curiam viam fuit universae carnis ingressus, sicque in causa ulterius minime fuit processum. Petrus subrogatur dicto Petro de Vico in omni jure quod habebat de dicta eccl. s. Jacobi non obst. in Nirvenen. et Belnen. eccl. canon. et praeb.; dimittat vero archipresbyteratum s. Affricani cum eccl. de Ruppescissa Aeduen., Vabren. et Ruthenen. di. In e. m. Albien. de Brya Parisien. ac Aureliacen. Claromonten. archidiaconis eccl. (A. 40, f. 333a: V. 101, ep. 604).

${ }^{35} \mathrm{El}$ documento que se menciona es la donación de una vestimenta dorada, con destino al altar de Nuestra Señora Santa María, aplicada por el alma de don Gonzalo, su tío, obispo que había sido de Mondoñedo. Como muestra de gratitud, los canónicos se comprometieron a rezar un Paternoster todos los domingos sobre la sepultura del mencionado don Gonzalo, en la capilla de Santa María Magdalena, en donde estaba sepultado. Ibidem, p. 571.
} 
ally hu vir o Deán et os outros homees boos do cabicko que se pode fazer ata que enviin pedir mercee a o Papa et a meu señor o Cardeal ${ }^{36}$.

La identificación del titular de la matriz estudiada páginas atrás, que ha permitido también completar la semblanza biográfica de quien fue un destacado eclesiástico gallego del primer cuarto del XIV, hasta hoy no bien conocida, es pretexto oportunísimo para abordar complementariamente la reconstrucción de su importante linaje. No es ésta, desde luego, una tarea fácil, puesto que hoy por hoy es imposible ofrecer conclusiones definitivas en relación con cuestiones muy concretas. Algunos autores, en realidad ya unos cuantos, intentaron con anterioridad ofrecer un cuadro claro y coherente del linaje y, aunque casi siempre proporcionaron nuevos documentos o referencias de interés, nunca obtuvieron unos resultados mínimamente satisfactorios. Tanto es así, que-como consecuencia principalmente de las frecuentes homonímias, observables incluso dentro de una misma generación ${ }^{37}$ - no son pocas ni precisamente irrelevantes las filiaciones por ellos propuestas que hoy, ya con una mayor información disponible, deben ser rectificadas o cuanto menos puestas en duda ${ }^{38}$.

Con tal sentido crítico, por tanto, en las páginas que siguen se ha intentado trazar y documentar con la mayor nitidez posible una visión panorámica, completa y ajustada, de los orígenes y primeros tiempos - desde mediados del XIII a los comienzos del XV- de la trayectoria del linaje. Aunque la documentación aportada en este caso es ya importante, lo que ha permitido corregir errores, rellenar lagunas y precisar contradicciones 293-302

${ }^{36}$ El texto completo en A. López Ferreiro, Galicia Histórica, CD, doc. núm. LXXI, pp.

${ }^{37} \mathrm{La}$ transmisión de nombres asociados a patronímicos, en razón de su uso por un antecesor de más o menos relieve es fenómeno natural y frecuentísimo entre los linajes medievales. Era, en primerísimo lugar, una fórmula más entre las varias que proporcionaban cohesión al grupo familiar. Pero, al propio tiempo, con ella se procuraba preservar la memoria histórica -la acordança-de sus grandes personajes, de cuyo poder y prestigio social participaban inevitablemente los nuevos vástagos así bautizados. Nombres y patronímicos tales como, por ejemplo, García Rodríguez en el caso de los Valcárcel, Fernán Pérez en el de los Andrade, o Alonso López en el de los Lemos, se hicieron célebres y carismáticos en la Galicia bajomedieval, lo que no quiere decir que entre los demás linajes, incluso entre los más modernos o peor situados, no se produjera también la comentada reiteración. Y los Moscoso, como se indica en el texto, no fueron naturalmente una excepción: las denominaciones asociadas, caso de los Lope Pérez, Gonzalo Pérez o Rui Sánchez, adquirieron particular significación, portándolos simultáneamente en efecto varios personajes dentro de una misma generación.

${ }^{38}$ Ocurre así, por ejemplo, en Fr. F. DE LA GÁNDARA, Armas y triunfos de los hijos de Galicia, Madrid, 1662 [edic. facsmile de "Bibliófilos Gallegos", en Compostela, 1970], pp. 478-489. 
anteriores, todavía quedan algunos aspectos oscuros. Para su resolución se proponen, siempre con las naturales reservas, unas hipótesis de trabajo coherentes y en la medida de lo posible ajustadas también al amplio conjunto de referencias recopiladas hasta hoy por otros autores.

\section{El LINAJE DE LOS MosCOSO EN LOS SIGLOS XIII Y XIV}

La historiografía medieval gallega apenas se ha ocupado de las grandes estirpes y mucho menos todavía de considerar su estructura interna, relaciones y alianzas. Consecuentemente, es poco y muy confuso también lo que se sabe respecto a sus orígenes sociales. En el caso que nos ocupa el vacío tiene cierta justificación ante la pérdida, en el pasado siglo, del grueso de la documentación medieval gallega que formó parte del gran archivo de la Casa de Altamira ${ }^{39}$. Por fortuna, la todavía reciente localización de unos índices documentales, destinados a la administración de los patrimonios gallegos de ésta y formados con regestas en la mayoría de los casos muy completas, permiten contemplar con optimismo la posibilidad de un futuro estudio monográfico con métodos renovados y objetivos ambiciosos ${ }^{40}$.

La Casa de Altamira, forjada al amparo del señorío de Santiago, ocupó un lugar indudablemente relevante en el concierto nobiliario del siglo XV gallego. No obstante, el protagonismo de los Moscoso, linaje en torno al cual se vertebraría aquélla, es bien patente ya desde las décadas centrales de la centuria anterior, consecuencia en buena medida de su autorizada presencia

\footnotetext{
${ }^{39}$ Los documentos gallegos, al menos por lo que se sabe, fueron vendidos de manera vergonzante y destinados por sus compradores a servir de envoltorio para sus mercancias. Mejor suerte alcanzaron otros fondos documentales de la Casa de Altamira, que hoy se reparten distintas instituciones culturales: el Instituto Valencia de Don Juan y la Biblioteca Zabálburu, en Madrid, así como la British Library, de Londres, y la Biblioteca Pública Universitaria, de Ginebra. Amplia información sobre el tema en G. DE ANDRÉS, La dispersión de la valiosa colección bibliográfica y clocumental de la Casa de Altamira, "Hispania", XLVI (1986), pp. 587-635. Véase una breve referencia en X. Ma ${ }^{a}$. Lema SuÁrez y R. Mouzo Lavandeira, $O$ Castelo de Vimianzo e os Moscoso de Altamira, A Coruña, 1998, p. 31.

${ }^{40}$ Véase, M. BujÁN Rodríguez, Catálogo archivístico de monasterio de benedictinas de San Payo de Antealtares, Santiago de Compostela, 1996. Este valioso e interesantísimo fondo documental está siendo objeto de estudio por la Lcda. Ana Framiñán Santas, con vistas a su tesis doctoral, elaborada bajo la dirección de los Dres. Fernando López Alsina y Eduardo Pardo de Guevara y Valdés. A ella, así como a los Dres. Mercedes Vázquez Bertomeu e Isidro García Tato, los tres miembros del equipo de investigación del Proyecto As fortalezas medievais de Galicia (XUGA 40101B97), le son deudoras estas páginas por la colaboración prestada en la localización de algunas noticias y referencias documentales.
} 
en la Iglesia gallega, donde un buen número de sus miembros ocuparon importantes dignidades; los ejemplos más singnificativos lo ofrecen don Alonso, obispo de Mondoñedo, y sobre todo su hermano don Rodrigo, mencionado a veces como obispo de Salamanca, quienes gobernaron la mitra compostelana entre los años 1366 y 1382.

Las genealogías antiguas, conservadas al igual que los aludidos índices en el archivo de San Pelayo, de Santiago, coinciden en mencionar como cabeza de ella $-\mathrm{y}$, como se verá, con toda razón desde luego- a un rico cibdadano compostelano, don Pedro Vidal, de cuyo propio linaje nada se sabe. Se le podría suponer hijo de un Vidal de Moscoso y nieto de otro Pedro Vidal, pues así lo expresan algunas de las genealogías de San Pelayo y otras elaboradas también en los siglos pasados ${ }^{41}$. Contemporáneo suyo $-\mathrm{y}$ posiblemente pariente muy próximo también - lo fue otro don Pedro Vidal, al cual se documenta como abad del monasterio de San Martiño, de Santiago, allá por los años 1248 y $1249^{42}$. En cualquier caso, el don Pedro Vidal que cabe considerar por el momento cabeza del linaje de los Moscoso ha dejado un abundante rastro documental. Entre los fondos del archivo - hoy también desperdigado- del viejo convento de Santa Clara, de Santiago, se descubre un amplio conjunto de documentos - todos de adquisiciones de bienes, por compra o donación, en Compostela y su entorno próximo- de entre los años 1244 y $1283^{43}$. Aunque éstos no son los únicos rastros documentales que pueden encontrarse ${ }^{44}$.

\footnotetext{
"Gándara recuerda al respecto que «Don Joseph Pellizer dize que Pedro Vidal fue hijo de don Vidal, a quien pone por tronco de esta familia. I io digo, que lo fue Pedro Vidal, aquel ricohombre que io dexo advertido en tiempos del rey don Fernando, el de León; el qual firma con otros la escritura de fundazión del Monasterio de Monte de Ramo, fundado por la Reina doña Teresa de Portugal, i latinizó su apellido con tanto afecto, diciendo: Petrus Vidularis. Conf.». Véase, Armas y triunfos, p. 478.

${ }^{42}$ M. Lucas Álvarez, El archivo del monasterio de San Martiño de Fora, o Pinario, de Santiago de Compostela, A Coruña, 1999, vol. I, pp. 162-163, docs. 120, 121 y 122.

${ }^{43}$ Véanse las referencias en C.C. RodRíGUEZ NúÑ̄EZ, La colección diplomática de Santa Clara de Santiago (1196-1500), "Liceo Franciscano", 136-138 (1993), pp. 23-33, docs. 19, 20, 30, $36,39-52,55,66,73-74,76-78,83-84,91$ y 98.

${ }^{44}$ Valga sólo por ejemplo que, entre los fondos del monasterio de San Martín, hoy en el Archivo Histórico Diocesano, de Santiago, se conserva el intercambio otorgado en 1257 entre don Pedro Vidal, en nombre del Hospital de Santiago, y el abad y convento de San Martiño, por el que el primero entrega «toda la heredad que tiene el Hospital en el coto y feligresía de Santiago de Buxán», recibiendo en compensación "la mitad de los agros que tiene cerca de la ciudad de Santiago». La referencia en M. LUCAS ÁlvarEZ, El Archivo del monasterio de San Martiño de Fora, vol. I, p. 351, doc. 326.
} 
El sólo recuento de los bienes contenidos en este conjunto de adquisiciones, que será preciso suponer parte de un montante mayor, aunque hoy desconocido, da idea de la elevada posición y poderoso influjo que este burgués debió alcanzar en la Compostela de mediados del XIII. Por ello, pero también por el interés que seguramente tendrá desde otras perspectivas, vale la pena relacionarlas siguiendo el orden cronológico: en 1244, bienes en Taramunio, feligresía de Sancti Vicencii de Vigo, comprados por 20 sueldos leoneses ${ }^{45}$, y dos casas en la plaza del Campo, de Santiago, por 800 sueldos leoneses ${ }^{46}$; en 1253, la tercera parte de una casa en la rua da Penna, aquí Pigna, también en Santiago, por 90 sueldos leoneses ${ }^{47}$; en 1257, varias heredades en el lugar

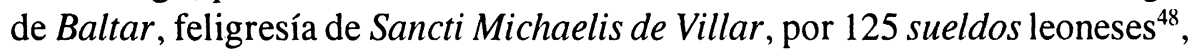
así como la mitad de una cortiña, sita prope ortum Bonavalle, y la mitad de dos casas en la rua da Penna, aquí Pigan, por 80 libras leonesas ${ }^{49}$. El conjunto de adquisiciones hechas a lo largo de 1258 es con notable diferencia el más importante: la tercera parte de una mitad de dos casas con su cortiña en la rua da Penna, por donación de doña Mayor Alfonso ${ }^{50}$; la octava parte de estas dos casas de la rua da Penna, por donación de doña Urraca Alfonso $^{51}$; la tercera parte de una mitad de estas dos mismas casas de la rua da Penna, por donación doña Inés Alfonso ${ }^{52}$; una heredad en Tracio de Iuso, feligresía de Sancte Maríe de Trazo, comprada por 10 sueldos leoneses $^{53}$; la mitad de una cortiña y de dos casas en la rua da Penna, todo por 220 morabetinos leoneses ${ }^{54}$; dos terceras partes de un pardiñeiro, en la rua da Penna, por 57 sueldos leones ${ }^{55}$; unas heredades en Sucadio, feligresía de

\footnotetext{
${ }^{45}$ Archivo Histórico Diocesano de Santiago [en adelante AHDS], Fondo San Martín Pinario. Santa Clara, 48/88.

${ }^{40}$ Archivo del Convento de San Francisco [en adelante ACSF], Fondo de Santa Clara, 1/16.

${ }^{47} \mathrm{La}$ escritura se otorga a favor de Juan Pérez, clérigo, «comparanti in persona domni Petri Vitalis». ACSF, Fondo de Santa Clara, 1/27.

${ }^{48} \mathrm{ACSF}$, Fondo de Santa Clara, 1/33.

${ }^{49} \mathrm{ACSF}$, Fondo de Santa Clara, 1/36.

${ }^{50}$ AHDS, Fondo San Martín Pinario. Santa Clara, 48/107a.

${ }^{51}$ AHDS, Fondo San Martín Pinario. Santa Clara, 48/107b.

${ }^{52}$ AHDS, Fondo San Martín Pinario. Santa Clara, 48/107c.

${ }^{53} \mathrm{ACSF}$, Fondo de Santa Clara, 1/37.

${ }^{54} \mathrm{ACSF}$, Fondo de Santa Clara, 1/38.

${ }^{55}$ ACSF, Fondo de Santa Clara, 1/39.
} 
Sancti Martini de Rodiz, por 20 sueldos leoneses ${ }^{56}$; dos cuartas partes de dos casas en la rua da Penna, aquí Pena, por 6 libras leonesas ${ }^{57}$; la tercera parte de una mitad de las dos casas con sus cortiñas, por donación de don Martín Yáñez, dictus Cabeza, y su mujer doña Mayor Alfonso ${ }^{58}$; la mitad de una casa en la rua da Penna, por 8 libras y 2 sueldos leoneses ${ }^{59}$; cinco doceavas de un agro sito super murum cortine Bonevalis, y cinco doceavas de otro llamado Fonte de Pignario, por 55 sueldos leoneses ${ }^{60}$; una casa en la rua da Penna, por permuta que hizo de otra con Juan Pérez, dictum de Doey ${ }^{61}$, y finalmente otra casa en la rua da Penna, aquí Pigna, por 13 libras leonesas $^{62}$. Ya en 1259, dos séptimas de una casa en la rua da Penna, aquí nova da Penna, por 80 sueldos leoneses ${ }^{63}$; en 1261, dos tercias de una quinta y dos quintas de otra quinta de la quinta de la voz de Catoyras y un quiñón de la iglesia de Sancti Christofori de Vesenio, por 35 sueldos leoneses $^{64}$; en 1265, una casa en Nogueyra, feligresía de Sancte Christine de Veea, por 30 libras leonesas ${ }^{65}$; en 1267, varias heredades en Cima de Fonte de Lavandeyra y otros lugares de la feligresía de Sancti Christofori de Vesenno, por 25 sueldos leoneses ${ }^{66}$; en 1268 , una heredad en Villa de Couso y otros lugares en la feligresía de Sancte María de Couso, por 100 sueldos leoneses ${ }^{67}$; en 1269 , dos casales, uno en Frochezo, feligresía de Sancti Mametis [de Ferreiros],

\footnotetext{
${ }^{56}$ La escritura se otorga a favor de Fernando Yáñez, «comparanti nomine et in voce domni Petri Vitalis", el cual acaso fuera su propio hijo. AHDS, Fondo San Martín Pinario. Santa Clara, $46 / 72$.

${ }^{57} \mathrm{La}$ escritura se otorga a favor de Juan Pérez, clérigo, «comparanti nomine et voci domni Petri Vitalis et vocis suem. ACSF, Fondo de Santa Clara, 1/42.

${ }^{58} \mathrm{ACSF}$, Fondo de Santa Clara, 1/41.

${ }^{59} \mathrm{La}$ escritura se otorga a favor de don Juan Martínez, «civi compostellano, comparante in voce et nomine domni Petri Vitalis omnique voci sue». ACSF, Fondo de Santa Clara, 1/40.

${ }^{60} \mathrm{ACSF}$, Fondo de Santa Clara, 1/43.

${ }^{61}$ La permuta a través de Diego Pérez, «agente nomine et voce domni Petri vitalis». ACSF, Fondo de Santa Clara, $1 / 44$.

${ }^{62}$ La escritura se otorga a favor de Diego Arias, dicto Pitenia, "comparanti nomine domni Petri Vitalis omnique voci sue». ACSF, Fondo de Santa Clara, 1/45.

${ }^{63} \mathrm{ACSF}$, Fondo de Santa Clara, 1/48.

${ }^{64} \mathrm{La}$ escritura se otorga a favor de Domingo Díaz, «comparanti in voce et nomine domni Petri Vitalis, domini vestri». ACSF, Fondo de Santa Clara, 2/7bis.

${ }^{65} \mathrm{ACSF}$, Fondo de Santa Clara, $2 / 13$.

${ }^{66} \mathrm{ACSF}$, Fondo de Santa Clara, 2/14.

${ }^{67} \mathrm{La}$ escritura se otorga a favor de Juan Pérez, «comparanti nomine et voce domni Petris Vitalis et vocis sue». ACSF, Fondo de Santa Clara, $2 / 16$.
} 
y otro en Cusanca, feligresía de Sancti Vereeximi [de Ferreiros], por 400 sueldos alfonsíes ${ }^{6}$, así como unas heredades en la feligresía de Sancti Christofori de Luivalde, por permuta de unos casales en Formaris, feligresía de Sancti Christofori de Enfesta, con Pelayo Yáñez, dictum Seixino ${ }^{69}$; en 1273, un quiñón completo de 40 quiñones del lugar de llamado de Pedra, feligresía de Sancti Simeonis de Oens, por 80 sueldos alfonsíes ${ }^{70}$, además de la octava parte de todo el lugar de Villa Nova, la octava parte también de otras marcas que entran en el lugar de Villam de Casal y otras heredades del mismo, en la feligresía de Sancti Iohannis de Recesende, todo por 440 sueldos alfonsíes $^{71}$; en 1278, por último, unas heredades en Maraes, feligresía de Sancte Christine de Veya, por 200 sueldos alfonsíes ${ }^{72}$.

El rastro documental de don Pedro Vidal se interrumpe en este último año, que es el probablemente el de su fallecimiento. De ahí justamente que la última adquisición consignada se otorgue ya a nombre sólo de su mujer, doña Teresa Sánchez. Por lo que parece también, don Pedro Vidal fue sepultado dentro de la basílica compostelana, en una pequeña capilla de su fundación, que sería ampliada y refundada un siglo después como panteón de su linaje, pero que originariamente sólo ocupaba el entrepaño de pared que daba salida a la Quintana, entre las antiguas capillas de San Nicolás y Santa Cruz ${ }^{73}$.

Hay constancia documental de dos matrimonios suyos. El primero es el contraído con doña María Fernández, hija de un tal don Fernán García de Leyra ${ }^{74}$. De esta primera unión nació cuanto menos un hijo, Fernán Eans de Leyra, del cual hay una primera noticia en el testimonio de fianza que a

\footnotetext{
${ }^{68} \mathrm{La}$ escritura se otorga a favor conjuntamente de doña Teresa Sánchez y don Pedro Vidal. ACSF, Fondo de Santa Clara, $2 / 17$.

${ }^{69}$ AHDS, Fondo San Martín Pinario. Santa Clara, $45 / 96$.

${ }^{70}$ La escritura se otorga a favor de Juan Pérez, edicto de Montanis, clerico, comparanti nomine et in persona domni Petri Vitalis et uxoris sue domne Tharasie Sanciim. ACSF, Fondo de Santa Clara, $2 / 21$.

${ }^{71}$ La escritura se otorga a favor de Juan Pérez, clérigo, "comparanti nomine et voce domni Petri Vitalis et uxoris sue, domne Tharasie». ACSF, Fondo de Santa Clara, 2/22.

${ }^{72}$ La escritura se otorga a favor de Pedro Yáñez, clérigo, "comparanti nomine et voce domne Tharasie Sancii». AHDS, Fondo San Martín Pinario. Samta Clara, 45/46.

${ }^{73}$ A. LóPEZ FERreiro, Historia de la Iglesia de Santiago, vol. VI, pp. 275-276.

${ }^{74}$ El personaje se documenta en 1242 con una donación al monasterio de San Martiño de «sus posesiones en San Salvador de Oor y San Xiao de Vilarchao, en Cabaleiros». La referencia - sin el significativo don que parece le correspondia- en. M. LuCAS Álvarez, El Archivo del monasterio de San Martiño de Fora, vol I, p. 161, doc. 115.
} 
su favor otorgó -el 1 de octubre de 1286- doña Teresa Sánchez, que se identifica como su madre, cuando en realidad era la ya citada segunda mujer de don Pedro Vidal. En este instrumento se explica que «don Fernán Garçia de Leyra, que foy avoo deste Fernán Iohanes, avía a quarta da villa d'Inssoa et que a devía a ver este Fernán Iohanes et sua voz, a qual villa é enna freegresía de sancta María de Seaureiro ${ }^{75}$. Es probable que don Pedro Vidal tuviera además algún otro hijo. Pudo serlo muy bien, por ejemplo, la doña Urraca Rodríguez a la que el obispo don Gonzalo de Moscoso menciona en su testamento junto con su marido, Pedro Miguélez Palla, y sus dos qqhijos, a los que trata precisamente de sobrinos suyos ${ }^{76}$. Y pudo serlo, asimismo, un personaje llamado Vidal Eans, a quien sólo se documenta muy tardíamente, en la primera mitad del XIV, pero que acaso podría sospecharse padre de un Juan Vidal do Camiño, cuya descendencia se sabe que hizo uso de los signos de identidad - nombres y patronímicos, apellido y armas- de los Moscoso descendientes de don Pedro Vidal, con los cuales mantuvieron además una relación de parentesco ${ }^{77}$.

\footnotetext{
${ }^{75}$ ACSF, Fondo de Santa Clara, 2/36. Este Fernán Eans es mencionado también en el testamento del obispo don Gonzalo, quien lo hace beneficiario de un lote de heredades y casas, señalando que «a sua morte dél que fique a sua filla María Fernández, mina sobrina...». Véase, en A. LóPEZ Ferreiro, Galicia Histórica, CD, doc. LXXI, p. 298.

${ }^{76}$ Son los que siguen: Gonzalo Pérez de Moscoso, canónigo de Mondoñedo y después arcediano de Montenegro, Ruy Sánchez de Moscoso, canónigo igualmente de Mondoñedo y después deán de esta misma Iglesia, y Estebo Rodríguez de Moscoso, padre a su vez de un nuevo Gonzalo Pérez de Moscoso, el cual vivió - junto con su mujer, doña Teresa Eáns Becerra- en una casa situada justamente en la compostelana rua da Penna. En este último personaje se descubre, probablemente, al propietario de uno de los testimonios sigilares aludidos páginas atrás. puesto que es el único de la estirpe con tal nombre y patronímico que no fue eclesiástico. A los dos primeros que se citan, Gonzalo Pérez y Ruy Sánchez, los menciona también el obispo don Gonzalo en su testamento, llamándoles además sobrinos suyos, y los mejora con los bienes de sus padres de conformidad con el poder que éllos le dejaron. Pasados los años, ambos clérigos fundaron sendos aniversarios por el alma de su tío, el obispo don Gonzalo. A. LóPEZ FERREIRO, Historia de la Iglesia de Santiago, VI, pp. 149-150. También, Fr. A. PARDo VILlaR, El convento de Santo Domingo de Santiago, "Boletín de la Comisión Provincial de Monumentos de Lugo" len adelante sólo BCML], IV, núm. 35 (1951), p. 232, y E. CAL PARDO, Episcopologio mindoniense, p. 572 .

${ }^{77}$ Del mencionado Juan Vidal do Camiño y de su mujer Elvira López, hija de un Lope Peláez, quedó por hijo un Lopo Sánchez de Moscoso, padre a su vez de Elvira Sánchez -ciasada con un Fernán López de Millar - y de Alfonso Sánchez, que lo fue finalmente de Ruy Sánchez de Moscoso, canónigo de Santiago y arcediano de Deza, quien por su testamento -otorgado en 1400 - dejó fundado el famoso Hospital de San Miguel do Camiño para pobres y peregrinos, designando por coadjutores e defensores de su testamento a Ruy Sánchez de Moscoso, señor de Altamira, y a su hijo Rodrigo de Moscoso, para que tomen dello cargo por o linaje que con eles aio. Hermano del aludido canónigo y arcediano pudo serlo también el escudero Sancho Sánchez de Moscoso, que se documenta como justicia de Santiago por 1399. Este último figura ya algunos años después, en 1419, junto con su mujer, una María Fernández, recibiendo del convento de
} 
El segundo y más conocido matrimonio de don Pedro Vidal fue el contraido con la ya mencionada doña Teresa Sánchez de Ulloa, el cual consta por muy diversos instrumentos ${ }^{78}$. Ella era miembro de una relevante estirpe gallega e hija, en concreto, de un gran personaje de los primeros años del XIV, don Sancho López de Ulloa, señor de Villamayor y repostero mayor de Sancho IV y Fernando IV ${ }^{79}$. En su mujer, doña María Ruíz de Lara, hubo también a don Lope Sánchez de Ulloa, con quien continuaría la línea de la gran Casa de Ulloa ${ }^{80}$.

Un documento revelador proporciona los nombres de los hijos nacidos de este segundo matrimonio de don Pedro Vidal, entre ellos - claro estáel del propio titular de la matriz sigilar estudiada en estas páginas ${ }^{81}$. Se trata

Santa Clara por voz de su abadesa, doña Teresa Sánchez de Moscoso, el foro de unas heredades en San Payo de Buscás, bienes que hasta poco antes había llevado doña Constanza de Moscoso. Véase, A. López Ferreiro, Historia de la Iglesia de Santiago, vol. VII, 123-127 y 183. El testamento del canónigo y arcediano Ruy Sánchez en "Galicia Diplomática", vol. III (1888), 325330 y A. ROdRíGUEZ GonzÁLEZ, El hospital de San Miguel del Camino para pobres y peregrinos. "Compostellanum", vol. XII (1967), pp. 225-232. Véase, también, C.C. RodRiGuEZ NúÑEZ La colección documental de Santa Clara, de Santiago, 200, doc. 885.

${ }^{78}$ El primero, probablemente de 19 de marzo de 1268: «Ego domina Tharasia Sancii, uxor domini Petri Vitalis... in remedium animarum nostrarum et domine Marine Fernandi. uxoris quondan domini Petri Vitalis...". Véase, Fr. A. PARDo VIllar, Los dominicos en Santiago. Aptuntes Históricos, Anejos de "Cuadernos de Estudios Gallegos", núm. VIII, Santiago de Compostela, 1953, p. 248

${ }^{79} \mathrm{La}$ rama mayor o principal del linaje. localizada en la Ulloa lucense desde las décadas centrales del XIII, puede trazarse a partir de un Lope Rodríguez de Ulloa, escudero, casado con doña Onega Odoari, mencionada por su hija doña Mayor López en la venta de dos casales en tierras de Ferreiros a su sobrina - sobrina nieta más exactamente- doña Teresa Sánchez. mujer de don Pedro Vidal. Hijos de aquéllos lo fueron también don Fernán López, don Vasco López y don Sancho López, casado con doña Urraca Pérez de Medín, y no de Sotomayor, como insistentemente se repite en los nobiliarios. Hijos de estos últimos fueron ya doña Constanza. señora de Medín, don Alvar Sánchez, señor de Felpós, don Lope Sánchez y, finalmente, el don Sancho Sánchez que se menciona en el texto. El testamento de este último, otorgado en 28 de mayo de 1217, en AHN, Clero, carp. 546/15. Véase, además. ACSF, Fondo de Santa Clara, $2 / 17$.

${ }^{80}$ L. Salazar y Castro. Historia genealógica de la Casa de Lara, vol. I, Madrid, 1694. pp. 184 y ss. La sucesión, aunque hoy ya bien conocida y suficientemente documentada. parece que se recogía en el epitafio del sepulcro - hoy desaparecido - del segundo nieto y homónimo de este Lope Sánchez, que fue enterrado monasterio de Sobrado: «Aquí iace Lope Sánchez de Ulloa, fijo de Gonçalo Osores de Ulloa y de dona María de Sotomayor, padre de don Sancho de Ulloa, conde de Monte Rey, falleció en el año de 1405 años. De otra parte diçe: fue fijo de Goncalo Osores y nieto de Basco López y biznieto de Lope Sánchez, reviznieto de Sancho Sánchez de Ulloa". Véase, Historia manuscrita del monasterio de Sobrado, Biblioteca del Instituto de Estudios Gallegos "Padre Sarmiento", fol. 183.

${ }^{81} \mathrm{La}$ filiación de Gonzalo Pérez se anota también en otro documento del 7 de junio de 1302 : «Era $\mathrm{M}^{\mathrm{a}} \mathrm{CCC}^{\mathrm{a}} \mathrm{XL}$ et quotum VII idus junii. Eu donna Mayor Pérez, filla que fuy de dom Pedro Vidal et de donna Thareya Sánchez dou et outorgo a abbadessa et aas donas do moesteyro de 
del acuerdo y cambio suscrito el 31 de marzo de 1283 entre la viuda -ahora casada de nuevo- y los hijos de don Pedro Vidal sobre los bienes que quedaron de éste, de manera que la primera recibió de los segundos las casas, casales y heredades que ellos tenían en Millán, feligresía de San Miguel de Vilar, así como otros casales y heredades en Soveredo, Cerzedo, Pignario y Porcariça, entregando ella a cambio las heredades de Fao, que le había donado su marido. Al propio tiempo, los hijos concedieron a la doña Teresa las casas de la rúa da Penna, en las que había vivido su padre, así como otras casas y heredamientos que éste poseía en Santiago, poniendo como condición que doña Teresa no podría venderlas, donarlas, cambiarlas, ni legarlas a otros, sino a ellos, hijos de Pedro Vidal. Además de todo ésto, la doña Teresa renunció a la parte que pudiera corresponderle en los bienes de don Pedro Vidal racione filie sue Tharasie Petri. El encabezamiento del instrumento es como sigue:

Era $\mathrm{M}^{\mathrm{a}} \mathrm{CCC}^{\mathrm{a}} \mathrm{XX}$, prima et quotum II" kalendas parilis. Hoc est pactum et placitum firmun in duobus millebus morabitinis bone monete roborarum inter domnan Tharasiam Sancii, presente et concedente viro suo Alvaro Pelagii ex una parte, et Iohannem Alfonsi de Cerveyra, pro se et pro uxore sua María Petri, et Lupum Petri, pro se et pro Gundisalvo Petri, fratre suo, et Alfonso Sancii, pro se et pro Maiore Petri, uxore sua, ex altera, videlicet, quod predictis uxoribus suis, et Lupus Petri pro se et pro dicto fratre suo dent sic et concedunt predicte domne Tharasie Sancii in concambium pro domibus et hereditatibus de Fao qua domnus Petrus Vitalis vir quondam predicte domne Tharasie Sancii donaverat eidem domne Tharasie in donatione propter nupcias. secundum quod in quodam instrumento per alphabetum diviso exinde confecto plenius continetur ${ }^{82} \ldots$

Así, pues, de don Pedro Vidal y su segunda mujer quedaron cinco hijos: doña María, doña Mayor, doña Teresa, don Lope Pérez y don Gonzalo Pérez, titular de la matriz sigilar y cuya trayectoria ha quedado trazada páginas atrás. El entorno familiar se completa con los maridos de las dos primeras

Santa Clara para aiuda de fazeren seu moesteyro, todo o meu quinón que eu ey nas casas et nas ortas de Santa Trinidade et en huna mesa de canbear nas tavoas et en todalas outras casas da villa de Santiago, salvo as en que morou meu padre et minna madre sobreditos et en que ora meu yrmano Gonçalvo Pérez mora, que son na rua da Pena...». Véase C.C. Rodríguez Núñez. El papel de la mujer en la sociedad medieval, Lugo, 1993, p. 311, doc. 8.

${ }^{82}$ ACSF, Fondo de Santa Clara, 2/32. 
que se mencionan: don Juan Alfonso de Cerveira, casado con la doña María ${ }^{83}$, y don Alfonso Sánchez, primer marido de la doña Mayor, el cual debió morir poco después, puesto que ésta figura casada después - cuanto menos desde los comienzos del XIV - con don Fernán Núñez de Aldán, o Maldonado, que llamaron Boquiñas ${ }^{84}$.

Finalmente, respecto al Lopo Pérez que se menciona en el documento arriba extractado es muy poco lo que puede decirse. Probablemente sea el mismo que, por 1273, ordenó a un mayordomo suyo, de San Vicenzo de Marantes, que no hiciera agravio a un monje de San Martín sobre una luctuosa en el burgo de Puente Sigüeiro, por cuanto él era morador alli ${ }^{85}$.. En todo caso, lo que importa destacar es que a través de este hijo de don Pedro Vidal se continua la línea de sucesión en torno a la cual se forjaría no mucho más tarde la gran Casa de Altamira. Así, aunque no haya prueba documental alguna al respecto, es fácil suponer que de este personaje - que estuvo casado con una Mayor Fernández-quedaron dos hijos varones: un nuevo don Lope Pérez y don Sancho López ${ }^{86}$.

El primero de ellos fue, seguramente, el Lopo Pérez I de que hablan las genealogías de San Pelayo y cuantos autores se han ocupado del linaje, suponiéndole siempre hijo $-\mathrm{y}$ no nieto como realmente creemos aquí- de don Pedro Vidal. Este nuevo personaje casó, según coinciden todos, con doña Mayor de Novoa y hubo en ella dos hijas únicamente: doña Constanza de

\footnotetext{
${ }^{83}$ El don Juan Alfonso de Cerveira era hijo de don Alfonso Pérez y de doña Teresa Pérez. ella hija de don Pedro Suárez - Sánchez más bien-Sarraça. Tras enviudar. doña María ingresaría en el convento de Santa Clara, del cual sería además abadesa, falleciendo finalmente en 1329 La ascendencia del don Juan Alfonso, por los Cerveira y Sarraça respectivamente, en los Livros velhos de Linhagens, edición crítica de J. Piel y J. Mattoso. Lisboa, 1980, vol. I. 148 (10H5) y 157 (11R10).

${ }^{84}$ Este personaje debió fallecer poco antes de 1308. En este año, el 23 de abril exactamente, doña Mayor otorgaba la renta de dos toneles de vino como dote al ingresar en el convento de Santa Clara, lo que apenas una semana después sería confirmado por los hijos de ambos. Véase. AHDS, Fondo de San Martín Pinario. Santa Clara, 47/126b y 126a. Ella vivió hasta 1327 cuanto menos. pues el 18 de enero de ese mismo año hizo donación al convento de Santa Clara, de Pontevedra, de "os banos que eu fige enna villa de Pontevedra, asy como están. con suas casas et con suas entradas et seydas, et con todas suas dereituras...". C.C. RODRÍGUEZ NúÑEZ, El papel de la mujer en la sociedad medieval, 316-317, doc. 14.

${ }^{85}$ M. Lucas Álvarez, El archivo del monasterio de San Martiño de Fora, vol. I, p. 360 , doc. 383 .

${ }^{86}$ En un pleito con motivo de la partición de bienes de Fernán Becerra de Cances, escudero, se hace referencia a cierta heredad que su viuda, doña María López de Moscoso, frecuentemente llamada también doña Mayor Fernández, afïmaba haber sido antes de su propio padre y de su abuela: don Sancho López y doña Mayor Fernández, cuyo nombre y patronímico justamente tomó su nieta como apelativo. AHDS, Fondo de San Martín Pinario. Santa Clara, 47/139.
} 
Moscoso, que casó con el famoso Fernán Pérez de Andrade $o$ Boo, aunque no hubo sucesión ${ }^{87}$, y doña María de Moscoso, que casó a su vez con Andrés Sánchez de Gres, merino mayor de Galicia, fallecido por 1368, dejando descendencia en este linaje ${ }^{88}$.

Pero, al no alcanzar el mencionado Lope Pérez un heredero varón, la línea de sucesión del linaje continuó en su ya mencionado hermano, don Sancho López, cuyo nombre y patronímico tienen un sonoro antecedente en el linaje de su abuela paterna ${ }^{89}$. En este nuevo personaje, que se documenta

\footnotetext{
${ }^{87}$ Se trata, como es bien sabido, de uno de los más caracterizados personajes gallegos de la segunda mitad del XIV. Miembro de una estirpe ya antigua pero no especialmente bien situada hasta poco antes. Al igual que otros muchos caballeros gallegos, el de Andrade se alineó al comienzo de la contienda civil en el bando de los legitimistas y, de ahí, le vinieron precisamente las primeras mercedes: ciertos juros de heredad sobre Recimil, Villalba y Santa Marta. Sin embargo, la valiosa colaboración que más tarde prestó al pretendiente fue su gran opción de futuro y las mercedes que la recompensaron fueron, al final, todavía más sustanciosas: por privilegio de 19 de diciembre de 1371 recibió las feligresías de Narahio. que habían sido del legitimista don Gonzalo Piñeiro, Recemil y Ferrera, además de las villas de Ferrol y Pontedeume, con todos sus alfoces; el 13 de agosto de 1373 recibiría además el señorío de Villalba, que había sido de don Fernando de Castro, y finalmente, el 6 de enero de 1377, las feligresías de "San Juan de Paderne, Santiago de Diágono, San Juan de Villamourel, Santalla de Viña, San Lorenzo de Iglesia, Santa María de Matares y San Martín de Borio..." El personaje no lograría sucesión de sus tres matrimonios, contraídos con doña Sancha Núñez Pardo. doña Teresa de Guzmán y la doña Constanza de Moscoso que se menciona en el texto. Por ello, el poderoso patrimonio reunido y el alto prestigio social alcanzado se transmitió por la línea de su hermano don Juan Freire. Esta circuntancia, dada la célebre cláusula testamentaria de Enrique II, sería motivo o pretexto de graves inconvenientes y conflictos durante la primera mitad del XV. Finalmente, la Casa de Andrade saldría intacta y alcanzaría la más alta posición entre la nobleza gallega al comienzo del XVI. Tras don Fernán Pérez. Ios titulares de la Casa de Andrade fueron sucesivamente: don Pedro Fernández [†1403], don Nuño Freire [†1431], don Fernán Pérez [†1470], don Diego de Andrade $[\dagger 1490]$ y el gran conde don Fernando [ $\dagger 1540]$, a quien sucedió su hija doña Teresa, casada con don Fernando Ruíz de Castro, cuarto conde de Lemos, por lo que la de Andrade quedó incorporada desde entonces en la de Lemos. Más información y panorama nobiliario en E. PARDO DE GUEVARA Y VALDÉS, Viejos y nuevos linajes en Galiciá al final de la Eadad Media. Una visión panorámica, en Catálogos de Exposiciones "Galicia Terra Única". vol. "Galicia románica y gótica", Ourense, 1997, pp. 263-283.

${ }^{88}$ Es uno de los representantes más significados de una estirpe de relieve que fïgura asentada en el castillo de Cira y su jurisdicción, aunque con intereses en Rodeiro, Deza, Cira... Constan. precisamente, sus enlaces con los Rodeiro, Bendaña, Pardo de Cela, Moscoso... y. ya después del conflicto, con los Sotomayor. Insua o Isorna, Novoa... El linaje ofreció otros personajes de relevancia durante la primera mitad del XIV, como el arzobispo don Martín y su sobrino don Alfonso, arcediano de Trastámara. hermano del don Andrés Sánchez de Gres que se menciona en el texto. La línea del linaje continuó después en otro don Andrés, hijo del anterior. que se tituló señor de Cira, Camba y Rodeiro, bienes estos últimos que había comprado su padre a doña Mayor Vázquez de Rodeiro, viudad de Alonso Suárez de Deza. Ibidem, nota 16. Véase, además, A. López Ferreiro, Historia de la Iglesia de Santiago, vol. VI, p. 34, nota 2.

${ }^{89} \mathrm{El}$ abuelo de doña Teresa Sánchez era, como queda anotado más arriba, don Sancho López. de Ulloa, hijo a su vez de Lope Rodríguez de Ulloa, documentado como testigo en 1269. Véase, ACL, Colección Piñeiro, vol. III, fol. 739.
} 
en 1327 contendiendo con el convento de Santa Clara por «las casas e paaços e ortas e cortiñas da Penna, que foron de don Pedro Vidal» ${ }^{90}$, se descubre al progenitor de una muy importante generación de la estirpe:

Lope Pérez [o Sánchez] de Moscoso, al que las genealogías llaman el segundo, aunque en realidad lo creemos ya el tercero, fue el que heredó a su tio homónimo, siendo propiamente ya señor de la Casa de Altamira. De sus andanzas no es mucho lo que se sabe, salvo de alguna que otra peripecia antes y durante la guerra civil ${ }^{91}$. Este personaje, que falleció probablemente hacia 1375 , estuvo casado con doña Berenguela Gómez y hubo en ella cuatro hembras y un sólo varón: doña Constanza ${ }^{92}$, doña Inés ${ }^{93}$, doña María - o MayorFernández ${ }^{94}$, doña Berenguela ${ }^{95} \mathrm{y}$, finalmente, Gómez Aras, o acaso mejor Pérez, al cual cabe identificar como canónigo y deán en la

\footnotetext{
${ }^{90}$ ACSF, Fondo de Santa Clara, 4/32.

${ }^{9}$ Así su presencia en las célebres vistas de Tejadillo, en el verano de 1354, junto a don Fernando de Castro y otros importantes personajes gallegos. Entre ellos, su propio hermano, Sancho Sánchez de Moscoso, así como Andrés Sánchez de Gres, Suero Yáñez de Parada, Fernán Yáñez de Sotomayor, Alfonso Gómez de Lira, Gonzalo Sánchez de Ulloa y Álvaro Rodríguez de Bendaña, algunos de los cuales figurarían después entre los más fieles valedores del petrismo gallego. Véase, Crónica del rey don Pedro, Biblioteca de Autores Españoles, vol. LXVI, Madrid, 1875. Año V, Cap. XXXII. Además, A. LóPEZ FERrEIRO, Historia de la Iglesia de Santiago, vol. VI, pp. 146, 148-150, 154, y Apéndices, 138.

${ }^{92}$ Casó sucesivamente con Juan de Ocampo y Luis Soga de Lobeira el deshonesto. De ellos fueron hijos, respectivamente, doña Teresa Eans, que falleció sin sucesión, y don Payo Mariño de Lobeira, señor de La Sierra y repostero mayor de Juan II.

${ }^{93}$ Casó con García Prego de Montaos, señor de Montaos, el cual casó después - la escritura de dote es ya de 1413 - con doña María de Limia. No parece que dejara sucesión.

"Casó con Gonzalo Díaz de Mesía, escudero y señor de San Tirso de Mabegondo, miembro de una estirpe muy vinculada a la órbita compostelana. Recibió foros del monasterio de Dormeá y finalmente - en 1383 - la propia encomienda. Hijo de ellos fue García Díaz de Mesía, sobre quien recayó la pena de excomunión en 1406 a causa de su intromisión en los bienes del mencionado monasterio. Véase, M. LuCAS ÁlVAREZ, El archivo del monasterio de San Martiño de Fora, II, pp. 873-874, docs. 9 y 10, y 879, doc. 42 .

${ }^{95}$ Casó con Martín Sánchez das Mariñas, hijo de Gómez Pérez el viejo, señor del coto de Cecebre, y de su mujer, doña Teresa Alfonso. El personaje participó activamente en la guerra civil, siendo recompensado primero por don Fernando de Castro con el coto de Cillobre y después, tras abandonar el legitimismo, por Enrique II, que le hizo merced del coto de Lubre. De este matrimonio quedaron por hijos, entre otros, Ares Pardo das Mariñas, señor de Las Mariñas, con descendencia bien conocida, así como doña Berenguela, doña Teresa, doña Constanza, doña María Fernández... El linaje y su descendencia desde un nuevo Gómez Pérez, nieto del personaje de referencia en C. VAAMONDE LORES, Gómez. Pérez das Mariñas y sus descendientes, La Coruña, 1917.
} 
Iglesia de Santiago, esto último a partir cuanto menos de 1378 y hasta $1384^{96}$.

Sancho Sánchez de Moscoso, que suele ser mencionado como heredero del señorío de Villar de Payo Muñiz, cerca de Allariz, así como de otras heredades en Bergantiños y Mosquera. Estuvo vinculado a la Orden de Santiago, de la que fue Comendador mayor, y murió en la batalla de Nájera, a la que había concurrido en las filas de don Enrique ${ }^{97}$. Consta su matrimonio con una doña Aldonza Vázquez Mosquera, en la que dejó dos hijos ${ }^{98}$. Fueron éstos, un Ruy Sánchez de Moscoso, que llamaron de Bergantiños ${ }^{99}$, y un Suero Vázquez Mosquera, cabeza del linaje apellidado Moscoso-Mosquera, de Sevilla, el cual casó con doña Teresa de Figueroa, hermana del maestre don Lorenzo Suárez, y más tarde con doña Inés Gutiérrez de Haro; se le documenta como señor de Molares - lo era en realidad por su segunda mujery veinticuatro de Sevilla ${ }^{100}$.

Alonso Sánchez de Moscoso, que fue obispo de Mondoñedo entre los años 1347 y 1366. De allí salió para suceder al malogrado don Suero de Toledo en el arzobispado de Santiago, extendiéndose su pontificado hasta el de $1367^{101}$.

Rodrigo de Moscoso, que sucedió a su hermano don Alonso al frente del arzobispado de Santiago, el cual rigió entre 1367 y 1382. Por su testamento, otorgado en 26 de abril de este último año, don Rodrigo dejó

\footnotetext{
${ }^{76}$ Véase. A. López Ferreiro, Historia de la Iglesia de Santiago, vol. VI, Apéndices, 152. Su semblanza en S. PORTEla PAZOS, Decanologio de la lglesia Catedral de Santiago, Santiago, 1944, pp. 135-137.

${ }^{97}$ Crónica del Rey don Pedro, Año XVIII, Cap. XII.

${ }^{98}$ Se la menciona como doña Alduara Vázquez de Arias Mosquera en La Casa de los antiguos señores que fueron de Villanueva de Barcarrota (Madrid, 1722), Biblioteca Colombina de Sevilla. Ms. 48631, fols. 63-64.

${ }^{99}$ De los cuatro personajes homónimos que se documentan en estas páginas es éste, sin duda, quien sostuvo pleito con doña Constanza de Moscoso, mujer de Fernán Pérez de Andrade o Boo. Ella era su tía en segundo grado y no su prima hermana, como afirma Gándara en sus anotaciones sobre el linaje. Véase, Armas y triunfos, p. 479.

${ }^{100}$ Las filiaciones de sus dos mujeres, asi como su descendencia, con semblanzas biográficas de algunos personajes, en R. SÁNCHEZ SAUS, Linajes sevillanos medievales, Sevilla, 1991, vols. I, pp. 207-209, y II, Ärbol LVII.

${ }^{101}$ Su cortísimo pontificado, de apenas un año de duración. en A. LóPEZ FERrEIRo, Historic de la Iglesia de Santiago, vol. VI, pp. 177-182.
} 
fundada la capilla llamada dos ferros, en el trascoro de la catedral compostelana ${ }^{102}$.

Gonzalo Pérez de Moscoso, que fue arcediano de Reina entre los años 1373 y 1389 , identificándose con tal dignidad en uno de los sellos mencionados páginas atrás ${ }^{103}$. En 1380 amplió la capilla de Sancti Spiritus, fundada por seu visabo don Pedro Vidal. En ella dispuso cuatro sarcófagos bien labrados, con arcaturas, torreones sobre las enjutas y ángeles con incensarios en los vanos de los arcos. Allí mandó trasladar entonces los restos del don Pedro Vidal y de su hermano el arzobispo don Alonso, reservando las dos sepulturas restantes para su sobrino Gómez Aras, deán de Santiago, y para él mismo ${ }^{104}$.

María López de Moscoso, que fue conocida también como Mayor Fernández, nombre y patronímico que usó en recuerdo de su abuela paterna. Casó con Fernán Becerra de Cances, escudero, de quien constan algunas compras de bienes entre los años 1331 y 1359 en tierras de Santa Maria y San Martín de Cereo, San Martín de Cances, San Juan de Xornes, San Cristóbal de Lema ${ }^{105}$. Los hijos nacidos de este matrimonio fueron: Lopo Pérez, o acaso Álvarez, a quien llamaron el Mo$z 0^{106}$, Inés Fernández ${ }^{107}$, Teresa Sánchez ${ }^{108}$, María Álvarez ${ }^{109}$,

\footnotetext{
${ }^{102}$ En su mencionado testamento, el prelado menciona a tres de sus hermanos. el arzobispo don Alonso, don Lope Pérez y doña María, madre de otro Lope Pérez, y a su sobrina Constancia Meléndez, a la cual cabe identificar con doña Constanza, una de las hijas de Lope Pérez. hermano del testador. Véase, A. LóPEZ FERrEIRO. Historia de la Iglesia de Santiago, vol. VI. pp. 182-216 y Apéndices, 154-159.

${ }^{103}$ Su filiación en la donación que hizo, en 1380, del «casal et herdade que chaman de Revoredo. que he ena frigrisía de Santa María Dardias, en que mora Fernán Carneiro, o qual foy de Sancho López de Moscoso, meu padre...”. Véase. A. López Ferreiro, Historia de la lglesia de Samtiago. vol. VI, Apéndices, 150.

${ }^{104}$ Ibidem, 276 y Apéndices, 157-159. Respecto al deán Gómez Aras, sobrino de este Gonzalo Pérez, véase lo anotado más arriba.

${ }^{105}$ En septiembre de 1360 doña María Lópęz -en el documento consta como Mayor Fernández - figura ya viuda de Fernán Becerra. Éste era hijo de Juan Becerra de Cances y de doña Mayor Gonzalez de Medín, quien dejó la quinta parte de su herencia al convento de Santa Clara, como consta en su testamento otorgado en 30 de marzo de 1350. Dos meses después, el 23 de mayo. Fernán Becerra y su hermano Ruy Fernández, hicieron partija de los bienes de sus padres. Las referencias documentales en C.C. RODRIGUEZ NúṄEZ, La colección diplomárica de Samta Clara, de Santiago, docs. 300, 390-393, 429-431, 446, 458 y 461. También, El papel de la mujer en la sociedad medieval, p. 185.

${ }^{106}$ Fallecido a comienzos de los ochenta soltero y sin sucesión. Le heredaron a partes iguales su madre y su hermano Martín Becerra, padre de Ruy Sánchez, futuro señor de Altamira: «do qual Lopo Peres o dito Martín Becerra havía ganados a sua parte destes bens adiante contidos desta dita terça parte da dita herdança do dito Johan Becerra, que ao dito Martín Becerra
} 
Juan Becerra, que fue canónigo de Mondoñedo ${ }^{110}$, y Martín Becerra de Cances, que fue mejorado por su padre, recibiendo además la herencia de sus hermanos Lopo Pérez y Juan Becerra, fallecidos sin sucesión.

La línea de los Moscoso, señores de la Casa de Altamira, se continuó en el mencionado Martín Becerra, casado con doña Urraca Rodríguez de Ocampo, quien pertenecía a una de las estirpes burguesas más relevantes de Santiago. Era hija de Fernán García de Ocampo - que lo era a su vez de García Pérez de Ocampo- y de doña Teresa Eáns de Tudela, quienes también fueron padres de Juan de Ocampo, alcalde de Santiago por 1371, doña Teresa Álvarez, freila de Santa Clara, doña María Vázquez, casada con Juan Núñez de Isorna, en quien hubo a don Álvaro de Isorna, futuro arzobispo de Santiago, y Bernal Yáñez de Ocampo, cibdadano de Santiago y a veces titulado caballero también, que fue sin duda el más carismático representante de su linaje. Hijos de los mencionados Martín Becerra y doña Urraca Rodríguez fueron Rui Sánchez, primogénito y heredero, Juan Becerra, que consta casado con una Violante

pertenecía...". Más adelante: “todo esto pertenece a Urraca Rodríguez, por sí y por sus hijos y de Martín Becerra, en razón y pago de la tercera parte de la herencia de Juan Becerra, que ficou ao dito Martín Becerra, seu hirmao, y por la parte de Lopo Pérez". AHDS, Fondo de San Martín Pinario. Santa Clara, 47/125. Véase, además, "Galicia Diplomática", IV (1889), p. 155.

${ }^{107}$ Consta su matrimonio con García Rodríguez de Valcárcel en intrumento otorgado en 12 de diciembre de 1383 con motivo de la partición de los bienes dejados por su padre, Fernán Becerra. También, en la cesión a su hermana doña Teresa Sánchez de unos casales, que le pertenecían por la partición que hizo con Ruy Sánchez de Moscoso, escudero. AHDS. Fondo de San Martín Pinario. Santa Clara, 47/125a y 125 b.

${ }^{108}$ Freila de Santa Clara desde 1367 , cuanto menos. Figura como abadesa desde julio de 1403 y lo fue probablemente hasta 1429. Véase, C.C. RODRÍGUEZ NúÑEZ, El papel de la mujer en la sociedad medieval, pp. 284-285.

${ }^{109}$ Casada con Juan Mariño de Rianxo, hermano de Rui Soga el Degollado, que heredó el mayorazgo fundado en 1378 por don Payo Mariño y doña Sancha, padres de ambos. El linaje era muy antiguo, documentándose su presencia en tierras de Noya y Muros ya desde los comienzos del XIII. En la nómina de sus personajes más representativos figuran varios trovadores célebres, como Martín Eans, autor recogido en el cancionero de la Vaticana, o el canónigo y acaso hermano del anterior Osorio Eáns, recogido a su vez en el cancionero Colocci Brancuti. A ellos cabría añadir a Payo Pérez, repostero mayor de Fernando IV, el famoso obispo orensano Vasco Pérez, de la primera mitad del XIV. La sola alusión a sus alianzas es ya muy significativa: los Churruchao, Sarraza, Valladares, Sotomayor, Aldao, Gres... y, ya mediado el XIV, además de los Moscoso, los Saz compostelanos, así como los Pardo de Cela, Valladares, Xunqueiras, Caamaño, Valladares, Sarmiento, Sotomayor... que es la época en que florecen el mencionado Ruy Soga el Degollado, su hijo Luis Soga el Deshonesto, mencionado más atrás, y su nieto Payo Mariño, señor de La Sierra y repostero mayor de Juan II.

${ }^{110}$ A éste, como a Lopo Pérez el Mozo, le heredaron su madre, «enas duas partes dos seus bens", y su hermano Martín Becerra, "en outra terceira parte». Véase, AHDS, Fondo de San Martín Pinario. Santa Clara, 47/125. 
López"', el escudero Gómez Prego, así como una María Álvarez y una Mayor Fernández, las cuales consta que quedaron menores de edad a la muerte de su padre, fallecido antes de $1383^{112}$.

El heredero fue, como ya queda dicho, el primero de los hijos mencionados, el cual recibió la Casa de Altamira directamente de su abuela doña María López, alias Mayor Fernández, según se deduce de los documentos particionales de 1367 y 1383. El personaje, al que Aponte apodó el Tuerto, heredó también los bienes de los Ocampo compostelanos - transimitidos por su tío Bernal Yáñez - como él mismo proclamaría al titularse «erdeiro universal de Bernald Eáns do Campo et parente mays propinco da linahee dos do Campo» $" 113$.

A partir de este último personaje, la línea de la Casa de Altamira está ya perfectamente documentada. Mientras tanto, los ya aludidos vínculos con los Becerra de Cances y Val de Veiga, así como con los Novoa, Andrade, Gres, Mesía, Montaos, Soga de Lobeira, Mariñas, Valcárcel... y, en la esfera compostelana, con algunas de sus más ricas estirpes burguesas - caso de los Palla, Tudela y Ocampo- convirtieron al linaje en pieza fundamental de la vida de toda la Tierra de Santiago. Su presencia fue, en este sentido, especialmente notoria desde las primeras décadas del XV y, mucho más aún, desde la segunda mitad del siglo, cuando monopolizó durante varias generaciones

\footnotetext{
"'Hijo de éstos parece que fue doña María de Moscoso, casada con Fernán Pérez de Andrade o Mozo, señor de la Casa de Andrade. Así consta al menos en el Tumbo Vermello de don Lope de Mendoza, fuente contemporánea de los personajes aludidos, pues se redactó en los años 1430-38: aquí, al tratar del castillo de las Engrov'as, su valle y tierra, se asienta lo que sigue: "E e sabido en como el dicho Juan Bezerra dispuso del dicho castillo e terra, e que lo dio en casamiento con su fija a Fernán Peres d'Andrade. fijo de Nuño Fleyre, e que por semejante via le dio las dichas felegrisías de Santa María de Queyjas e de Santa María d'Eixebre. que son de la dicha vuestra egllesia, non lo podiendo nin deviendo fazer...". Véase. A. Rodriguez González. O Tumbo Vermello, fol. $97 \mathrm{v}$.

1"Natural o bastardo de Martín Becerra fue un Gonzalo Becerra de Val de Veiga, a quien acaso deba identificarse con el personaje homónimo que fïgura, allá por 1395, como alcaide de La Coruña por Fernán Pérez de Andrade. Consta: en cambio, que tomó como propias, por ser herencia de su padre, las feligresías de Santa María de Berdia, Santa Cristina de Nemenzo y. Santa María de Molrran, las cuales vendió después a su medio hermano Rui Sánchez. En el Tumbo Vermello de don Lope de Mendoza se asienta esta venta, aunque se apostilla inmediatamente que son del Arzobispo y que el dicho Gonzalo Becerra ulas tovo fasta aquí sin título alguno que de vuestra señoría dellas toviese, e vuestra señoría dio lugar a ello por él seer vuestro criado...”. Véase. A. Rodríguez González, O Tumbo Vermello, fol. 97v

${ }^{113}$ Véase, A. López Ferreiro, Historia de la Iglesia de Santiago, vol. VI. Apéndices, 130 y 141. y VII, 30. También, "Galicia Diplomática". vols. II (1884), p. 218 y IV (1881), p. 155, y Fr. A. Pardo VILLAR, El comvento de Santo Domingo de Samtago, BCML, IV, núm. 35 (1951). p. 305.
} 
la pertiguería mayor de Santiago. Por lo demás, el título condal de Altamira, que coronó su ascenso social en 1475, y sus varias veces renovadas alianzas de entonces con los Andrade, así como con los Limia, Sotomayor, Ulloa, Osorio... son, al margen de otras muchas consideraciones posibles, los más claros exponentes de la posición que pronto alcanzó en el cuadro nobiliario de Galicia al fin de la Edad Media ${ }^{114}$.

\section{RÉSUMÉ}

L'article est structuré en trois parties: une description et analyse d'une matrice sigillée castellaine trrouvée en Avignon - premier objet d'étude de ces pages-. identification de son propietaire: l'ecclésiastique Gonzalo Pérez (mort en 1327) et le lignage nobiliaire auquel il appartient: Moscoso. L'auteur, dans cet étude pionnier dans l'historiographie galicienne, trace le portrait d'une figure de premier ordre dans le monde ecclésiastique de la Galice du Moyen Âge et fait une reconstruction de sa généalogie.

\section{SUMMARY}

The article has three parts: a description and analysis of a castilian sigilographical matrix found in Avignon - the first object of study in these pages-, the idetification of its owner: the priest Gonzalo Pérez (died in 1327) and the noble kingship to which he belongs: Moscoso. The author, in this first study within the galician historiography, draws a portrait of an important figure in the ecclesiastical world of Medieval Galice and reconstructs its genealogy.

\footnotetext{
${ }^{114}$ La sucesión de la Casa de Altamira en MARQUÉs DE SIETE IGLESIAS [A. de Vargas-Zúñiga], Tínulos y Grandezas del Reino concedidos por los Reyes de Castilla hasta la muerte de Fernando $V$ el Caíólico, Madrid, 1956, pp. 60-64. Una reciente aproximación con inclusión de abundantes referencias biográficas en X.M". Lema SuÁREZ y R. Mouzo LAVANDEIRA, $O$ Castelo de Vimianzo, pp. 15-33.
} 